\title{
FGF signaling regulates development by processes beyond canonical pathways
}

\author{
Ayan T. Ray, Pierre Mazot, ${ }^{1}$ J. Richard Brewer, ${ }^{2}$ Catarina Catela, ${ }^{3}$ Colin J. Dinsmore, \\ and Philippe Soriano
}

Department of Cell, Developmental, and Regenerative Biology, Icahn School of Medicine at Mount Sinai, New York, New York 10029, USA

FGFs are key developmental regulators that engage a signal transduction cascade through receptor tyrosine kinases, prominently engaging ERK1/2 but also other pathways. However, it remains unknown whether all FGF activities depend on this canonical signal transduction cascade. To address this question, we generated allelic series of knockin Fgfr1 and Fgfr2 mouse strains, carrying point mutations that disrupt binding of signaling effectors, and a kinase dead allele of Fgfr2 that broadly phenocopies the null mutant. When interrogated in cranial neural crest cells, we identified discrete functions for signaling pathways in specific craniofacial contexts, but point mutations, even when combined, failed to recapitulate the single or double null mutant phenotypes. Furthermore, the signaling mutations abrogated established FGF-induced signal transduction pathways, yet FGF functions such as cell-matrix and cellcell adhesion remained unaffected, though these activities did require FGFR kinase activity. Our studies establish combinatorial roles of Fgfr1 and Fgfr2 in development and uncouple novel FGFR kinase-dependent cell adhesion properties from canonical intracellular signaling.

[Keywords: FGF; craniofacial development; neural crest; ERK1/2; cell adhesion]

Supplemental material is available for this article.

Received July 26, 2020; revised version accepted October 13, 2020.

Classic models of receptor tyrosine kinase activation involve ligand binding, receptor dimerization, transactivation of the kinase domain, phosphorylation of intracellular tyrosines, and binding of effectors that orchestrate activation of downstream signaling pathways (Simon et al. 1991; Lemmon and Schlessinger 2010). Different thresholds in dimer strength and stability may also come into play, as well as signaling dynamics engaged by each downstream pathway (Vasudevan et al. 2015; Zinkle and Mohammadi 2018; Li and Elowitz 2019). For FGFRs, where downstream pathways have been particularly well studied, numerous lines of evidence point to ERK1/2 as the main effector of FGF signaling (Lanner and Rossant 2010; Brewer et al. 2016). Although characterization of effector binding to RTKs provides critical insights on signaling specificity, assessing relative pathway significance requires in vivo validation. A previous analysis showed that knock-in Fgfr1 point mutations disrupting binding of multiple signaling effectors, alone or in combination, did not recapitulate the $\mathrm{Fgfr}^{-/-}$phenotype despite eliminating ERK1/2 outputs, suggesting

Present addresses: ${ }^{1}$ INSERM Transfert, 75013 Paris, France; ${ }^{2}$ Department of Immunobiology, Yale University, New Haven, CT 06520, USA; ${ }^{3}$ Department of Neurobiology, University of Chicago, Chicago, IL 60637, USA.

Corresponding author: philippe.soriano@mssm.edu

Article published online ahead of print. Article and publication date are online at http://www.genesdev.org/cgi/doi/10.1101/gad.342956.120. involvement of additional FGF effectors (Brewer et al. 2015).

In mammals, 22 FGFs have been identified by sequence homology, with 18 acting as secreted ligands for four FGF receptors (FGFR1-4) (Ornitz and Itoh 2015; Brewer et al. 2016). Both Fgfr1 and Fgfr2 play critical roles in early development. Fgfr1-null mutants fail to gastrulate and exhibit a defect in epithelial to mesenchymal transition required for mesoderm formation (Deng et al. 1994; Yamaguchi et al. 1994; Ciruna and Rossant 2001). Recent studies of Fgfr1 and Fgfr2 mutants, however, have documented an earlier genetic background-dependent role for Fgfr1 in primitive endoderm and trophectoderm development (Hoch and Soriano 2006; Brewer et al. 2015; Kurowski et al. 2019) and a combined role for Fgfr1 and Fgfr2 in both of these lineages (Kang et al. 2017; Molotkov et al. 2017; Kurowski et al. 2019). Null mutants for Fgfr2 exhibit embryonic lethality at E10.5 associated with placenta deficiency and exhibit multiple additional defects including the absence of limb bud development (Xu et al. 1998; Yu et al. 2003; Molotkov et al. 2017).

(C) 2020 Ray et al. This article is distributed exclusively by Cold Spring Harbor Laboratory Press for the first six months after the full-issue publication date (see http://genesdev.cshlp.org/site/misc/terms.xhtml). After six months, it is available under a Creative Commons License (Attribution-NonCommercial 4.0 International), as described at http://creativecommons.org/licenses/by-nc/4.0/. 
Additional evidence further supports a role for Fgfr1 and Fgfr2 in craniofacial development, as conditional mutagenesis of Fgfr1 in cranial Neural Crest Cells (cNCCs) or of Fgfr2 in the epithelium leads to facial or palatal clefting (Rice et al. 2004; Hosokawa et al. 2009; Wang et al. 2013; Brewer et al. 2015), while deletion of both receptors in cNCCs prevents midface closure (Park et al. 2008). The development of the face involves the coordination of multiple morphogenetic processes including the formation of the frontonasal, maxillary, and mandibular processes, and their convergence at the midline. The pharyngeal arches (PA) that appear on each side of the future head are largely composed of cNCC-derived mesenchyme covered by surface ectoderm. The primitive mouth is flanked rostrally by the frontonasal prominence (FNP), laterally by the maxillary $(\mathrm{Mx})$ processes, and caudally by the mandibular (Man) processes. By embryonic day (E) 10.5, the FNP wraps around the nasal pits, which separate the medial (MNP) from the lateral (LNP) nasal processes. Rapid growth of the Mx and LNP then pushes the MNP to converge and the midface to close. Paracrine signaling between the facial ectoderm and the underlying cNCCderived mesenchyme is particularly important for craniofacial morphogenesis, implicating FGF8 in mandibular development (Trumpp et al. 1999; Shigetani et al. 2000) and midface integration (Griffin et al. 2013). However, the signaling mechanisms by which FGFs regulate craniofacial development have not been elucidated, making this an excellent model system for interrogation.

FGFs are known to regulate cell proliferation and survival through canonical RTK signaling and regulation of gene expression, but are also known to regulate cell-matrix (Meyer et al. 2012) or cell-cell adhesion (Rasouli et al. 2018; Sun and Stathopoulos 2018; Kurowski et al. 2019) through other less well-established mechanisms. It remains unclear whether all activities engaged by the FGF receptors are dependent on activation by FGFs, on signaling through the kinase domain, or whether the receptors can engage cell adhesion receptors through interactions of their extracellular domains or by acting as scaffolds in specific cell surface compartments. Our previous results on signaling pathways operating downstream of FGFR1 (Brewer et al. 2015), although suggestive of additional signaling pathways, were difficult to interpret due to expression of FGFR2. The in vivo functions of FGFR2 signaling effectors are still largely unknown, however evidence to date indicates that signaling through FRS2 is not required during development (Eswarakumar et al. 2006; Sims-Lucas et al. 2009). In this work, we use constitutive signaling and kinase dead mutations as well as conditional mutations in the craniofacial mesenchyme, to understand which pathways coordinate FGF signaling at a developmental and biochemical level. We found that signaling mutations for each receptor disrupt classical signal transduction pathways in the absence of the other receptor, but do not recapitulate the null phenotypes. We furthermore show that FGF activity is kinase-dependent and identify FGF outputs independent of canonical signaling that help reconcile the gap in our phenotypic analyses.

\section{Results \\ Fgfr1 and Fgfr2 genetically interact in craniofacial development}

To interrogate FGFR1/2 functions in development and their role in supporting each other's activity, and to establish a baseline to study cell signaling mutations, we initially investigated how loss of both receptors in cNCCs influences craniofacial development. We found both receptors extensively coexpressed in the cNCC-derived mesenchyme and overlying epithelia, using fluorescent Fgfr1 and Fgfr2 reporter alleles (Molotkov et al. 2017). Fgfr1 expression was observed primarily in the mesenchyme (Fig. 1A, green arrow). In contrast, strong Fgfr2 expression was seen in the epithelia except for a small domain surrounding the nasal pit (Fig. 1A, yellow asterisk). Weaker widespread Fgfr2 expression was also observed within the mesenchyme (Fig. 1A, red arrow), indicating that both Fgfr1 and Fgfr2 are coexpressed in multiple regions.

Conditional null alleles (henceforth denoted $c K O$ ) of Fgfr1 and Fgfr2 were combined with Wnt1Cre drivers active in NCCs (Danielian et al. 1998; Lewis et al. 2013). Both Fgfr1 and Fgfr2 conditional null alleles create frameshift mutations early in the coding region likely leading to nonsense mediated decay, and if not, only a short peptide fragment unable to interact with ligands or any known effectors (Hoch and Soriano 2006; Molotkov et al. 2017). Throughout this work, all Fgfr1, Fgfr2, and Cre driver alleles were analyzed on a 129S4 coisogenic background, to avoid phenotypic variations that might be attributable to second-site modifiers. At E18.5, Fgfr $1^{\mathrm{cKO} / \mathrm{cKO}}$ embryos displayed a fully penetrant facial cleft while $\mathrm{Fgfr} 2^{\mathrm{cKO} / \mathrm{cKO}}$ mutants had no overt phenotype. Loss of Fgfr2 significantly enhanced the phenotype of $F g f r 1^{c K O / c K O}$ conditional mutants, and Fgfr $1^{c K O / C K O} ; \mathrm{Fg} f \mathrm{r}^{\mathrm{cKO} / \mathrm{cKO}}$ double mutants exhibited severe agenesis of most NCC-derived craniofacial structures including the frontal and nasal bones, nasal cartilage, maxilla, and mandible (Fig. 1B; Supplemental Fig. S1A). Both Fgfr $1^{\mathrm{CKO} / \mathrm{cKO}} ; \mathrm{Fgfr}^{+/ \mathrm{cKO}}$ and Fgfr $1^{c K O / c K O} ; F_{g} f 2^{c K O / c K O}$ embryos exhibited defects in mandible development, affecting proximal structures including angular and coronoid processes (Supplemental Fig. S1B). FGFR1 and FGFR2 are thought to function predominantly in mesenchymal or epithelial contexts, respectively, since Fgfr1c mutants recapitulate many aspects of the $\mathrm{Fgfr}^{-/-}$phenotype (Partanen et al. 1998), and Fgfr2b mutants are reminiscent of $\mathrm{Fgfr}^{-/-}$embryos (De Moerlooze et al. 2000). However, our results suggest that both receptors function coordinately within the neural crest and combined loss of Fgfr1 and Fgfr2 together in cNCCs leads to a significantly more severe defect than loss of either receptor alone.

The anterior part of the craniofacial skeleton, including the maxilla and mandible, nasal cartilage, Meckel's cartilage, frontal bone, and anterior cranial base (ethmoid and sphenoid bones), are derived from NCCs. Skeletal preparations revealed an anteriorly truncated skull due to loss of the nasal cartilage in $\mathrm{Fgfr}^{\mathrm{cKO} / \mathrm{cKO}} ; \mathrm{Fgfr} 2^{\mathrm{cKO} / \mathrm{cKO}}$ mutants at E14.5 (Supplemental Fig. S1C). Meckel's 


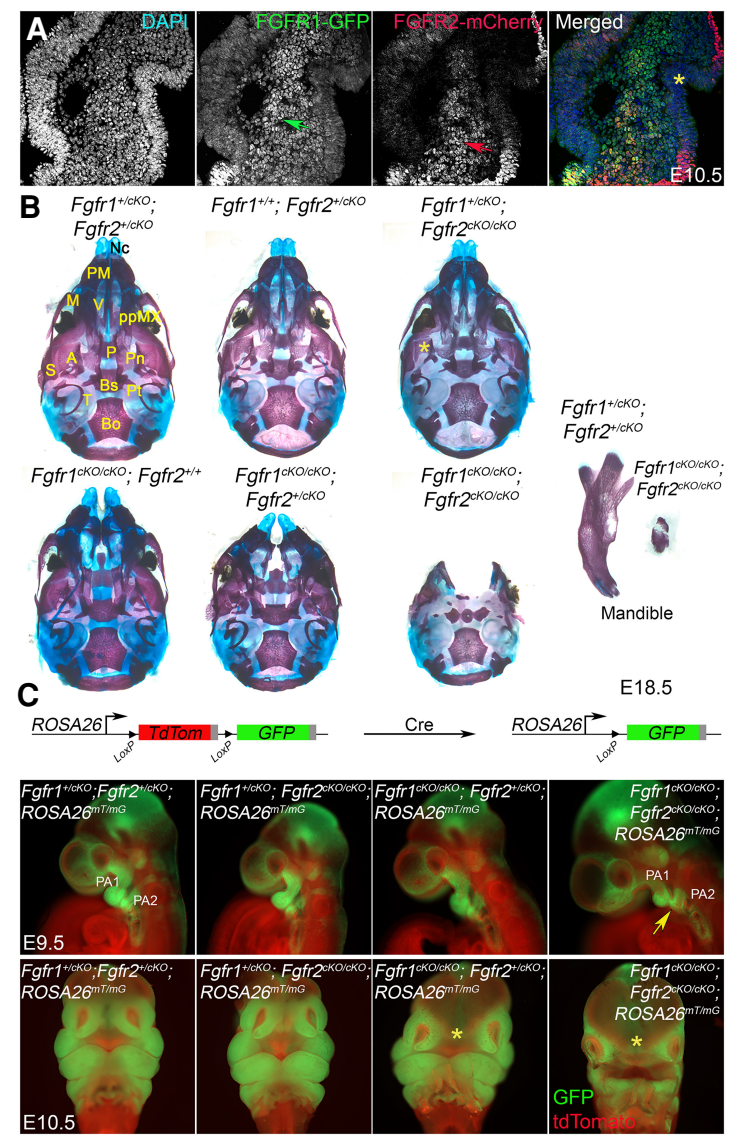

Figure 1. Defects in craniofacial morphogenesis in Fgfr1/2 double mutants. (A) Spatial domain of Fgfr1 and Fgfr2 expression in facial prominences at E10.5. GFP and mCherry immunohistochemistry were used to detect expression from Fgfr1-GFP and Fgfr2-mCherry reporter alleles. GFP expression was primarily restricted to the mesenchyme (green arrow). Although mCherry expression was restricted to the epithelium, many cells in the mesenchyme also express mCherry (red arrow). mCherry expression was down-regulated in the epithelium lining the nasal pit (yellow asterisk). (B) Inferior view (mandibles removed) of alcian blue/alizarin red staining of mouse skulls at E18.5 showed a facial cleft in $F g f r 1^{c K O / c K O}$ embryos, which was exacerbated in Fgfr ${ }^{\text {cKO/cKO }}$; Fgfr2 ${ }^{+/ c K O}$ mutants. Although $\mathrm{Fgfr}^{+/ c K O}$; $\mathrm{Fgfr} 2^{\mathrm{cKO} / \mathrm{cKO}}$ mutants did not show an overt midline defect, the alisphenoid was hypoplastic, affecting the forming processes (yellow asterisk). $\mathrm{Fgfr}^{\mathrm{cKO} / \mathrm{cKO}} ; \mathrm{Fgfr}^{\mathrm{cKO} / \mathrm{cKO}}$ mutants exhibited the most severe defect, with agenesis of medial and proximal structures as well as severe reduction of the mandible. (A) Alisphenoid, (Bs) basisphenoid, (Bo) basioccipital, $(\mathrm{M})$ maxillary, $(\mathrm{Nc})$ nasal cartilage, $(\mathrm{P})$ palatal, $(\mathrm{PM})$ premaxillary, $(\mathrm{ppMx})$ palatal process maxillary, $(\mathrm{Pt})$ pterygoid, $(\mathrm{Pn})$ palatine, $(\mathrm{T})$ tympanic bulla. $(C)$ Conditional Fgfr1-Fgfr2 null mutant embryos carrying the $R O S A 26^{m T / m G}$ reporter analyzed in whole mount. Schematic of reporter mouse design showing GFP (green) expression upon Cre expression in cNCCs (green). (Top) At E9.5, Fgfr $1^{\text {cKO/cKO }}$ Fgfr ${ }^{c K O / c K O} ; R O S A 26^{m T / m G}$ embryos showed reduced GFP fluorescence and had hypoplastic pharyngeal arches PA1 and PA2 (yellow arrow). $\mathrm{Fgfr}^{+/ c K O} ; \mathrm{Fgfr}^{\mathrm{CKO} / c K O}$ and $\mathrm{Fgfr}^{\mathrm{cKO} / \mathrm{cKO} \text {; }}$ $\mathrm{Fgfr}^{+/ \mathrm{cKO}}$ mutants appeared normal at this stage. Frontal view at E10.5 (bottom) shows a wide midline separation in both $\mathrm{Fgfr}^{\mathrm{cKO} / \mathrm{cKO}} ; \mathrm{Fgfr}^{+/ \mathrm{cKO}} ; \mathrm{ROSA}_{2} 6^{\mathrm{mT} / \mathrm{mG}}$ and $\mathrm{Fgfr} \mathrm{C}^{\mathrm{cKO} / \mathrm{cKO}}$; Fofr $2^{\text {cKO/cKO }} ;$ ROSA $26^{m T / m G}$ mutants (yellow asterisk). cartilage, a transient cartilage structure that directs the formation of bony mandible, was significantly reduced in Fgfr1 ${ }^{c K O / c K O} ; \mathrm{Fgfr}^{+/ c K O}$ and $\mathrm{Fgfr}^{\mathrm{cKO} / \mathrm{cKO}} ; \mathrm{Fgfr}^{\mathrm{cKO} / \mathrm{cKO}}$ mutants (Supplemental Fig. S1C). We observed reduced or absent alizarin red staining in the mandible and maxilla of Fgfr1 ${ }^{c K O / c K O} ; F_{f f r}{ }^{+/ c K O}$ and Fgfr1 ${ }^{c K O / c K O} ; F_{f f r}{ }^{c K O / c K O}$ mutants. Micro-CT analysis at E18.5 further demonstrated reduced ossification of NCC-derived structures in the anterior skull and mandible (Supplemental Fig. S1A).

Skeletal differentiation is a multistep process starting with formation of cartilage progenitors prior to terminal differentiation into bone. To investigate the role of FGF signaling during skeletal differentiation, we analyzed the expression of chondrogenic (Col2a1) and osteogenic (Col10a1) markers, first at E14.5 when cartilage progenitors are formed, and then at E17.5 when terminal differentiation is largely complete (Supplemental Fig. S1D). At E14.5, Col2a1 was expressed in a broader domain in $\mathrm{Fgfr}^{+/ \mathrm{cKO}} ; \mathrm{Fgfr}^{+/ c K O}$ anterior cranial base NCCs than in Fgfr $1^{\mathrm{cKO} / \mathrm{CKO}} ; \mathrm{Fgfr}^{\mathrm{cKO} / \mathrm{cKO}}$ mutants (Supplemental Fig. S1D), suggesting that skeletal differentiation is initiated but delayed in double null mutants. By E17.5, while Col2a1 was expressed at similar levels in both controls and Fgfr $1^{c K O / c K O} ; F g f r 2^{c K O / c K O}$ double mutants, Col10a1 was undetectable in double null mutants (Supplemental Fig. S1D), indicating a block in terminal differentiation. The observation that FGF signaling is important for skeletal differentiation is consistent with previous studies of differentiation in long bones (Karuppaiah et al. 2016).

Craniofacial defects in Fgfr1 and Fgfr2 conditional mutants are associated with cell death

At E9.5 and E10.5, Fgfr1 ${ }^{\mathrm{CKO} / \mathrm{cKO}_{;}} \mathrm{Fgfr}^{\mathrm{CKO} / \mathrm{cKO}}$; ROSA26 $6^{\mathrm{mT} / \mathrm{mG}}$ double mutants developed hypoplastic pharyngeal arches with reduced NCC lineage $\mathrm{GFP}^{+}$cells (Fig. 1C). Although $\mathrm{GFP}^{+}$NCCs were distributed throughout their migration streams at E9.5, the PA1 and PA2 arches appeared hypoplastic in double mutants (Fig. 1C, yellow arrow). By E10.5, Fgfr $1^{\mathrm{cKO} / \mathrm{cKO}} ; \mathrm{Fg} f \mathrm{r} 2^{\mathrm{cKO} / \mathrm{cKO}} ; \mathrm{ROSA}_{2} 6^{\mathrm{mT} / \mathrm{mG}}$ double mutants were morphologically identifiable with wider midline separation and hypoplastic MNP, LNP, and maxillary and mandibular prominences (Fig. 1C, yellow asterisk). A similar wide midline separation was also observed in Fgfr $1^{\mathrm{cKO} / \mathrm{cKO}} ; \mathrm{Fgfr}^{+/ c K O} ; \mathrm{ROSA}_{2} 6^{\mathrm{mT} / \mathrm{mG}} \mathrm{mu}-$ tants (Fig. 1C, yellow asterisks). We observed reduced expression of facial prominence markers along with midline morphogenesis defects, but ectoderm gene expression remained unaffected, suggesting reduced NCC numbers rather than patterning defects (Supplemental Fig. S2A).

We observed reduced fluorescence from $\mathrm{GFP}^{+}$cells in the mid-face of $\mathrm{Fgfr} 1^{\mathrm{cKO} / \mathrm{cKO}} ; \mathrm{Fgfr} 2^{\mathrm{cKO} / \mathrm{cKO}} ; \mathrm{ROSA} 26^{\mathrm{mT} / \mathrm{mG}}$ mutants at E9.5, which became more noticeable by E10.5, suggesting a reduction in cNCC numbers (Fig. 2A). We determined the percentage of $\mathrm{GFP}^{+} \mathrm{cNCCs}$ at E10.5 using flow sorting of single-cell suspensions from the facial prominences for all genotypes. Fgfr $1^{\text {cKO/cKO; }}$ Fgfr2 ${ }^{c K O / c K O} ; R O S A 26^{m T / m G}$ double mutants showed a $50 \%$ reduction in the number of $\mathrm{GFP}^{+}$cells relative to 
controls (Fig. 2B). We did not observe a significant reduc-

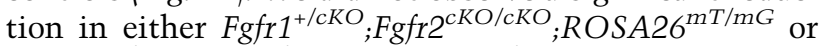
Fgfr $1^{c K O / c K O} ; F_{f f r 2}{ }^{+/ c K O} ;$ ROSA $26^{m T / m G}$ mutants, suggesting that the skeletal defects observed at E14.5 or E17.5 result from both reduction in NCC numbers as well as an FGF-dependent skeletal differentiation defect.

A reduction in NCC numbers in the midface might occur due to reduced proliferation, increased cell death, or both. Cell proliferation remained unaffected (Supplemental Fig. S2B); however, we observed increased cell death in $\mathrm{Fgfr} 1^{\mathrm{cKO} / \mathrm{cKO}} ; \mathrm{Fgfr} 2^{\mathrm{cKO} / \mathrm{cKO}} ; \mathrm{ROSA}_{2} 6^{\mathrm{mT} / \mathrm{mG}}$ E10.5 mutants in the craniofacial mesenchyme, notably in the LNP relative to the MNP (Fig. 2C,D). We next asked to what extent this observation could explain the overall morphological defects. The BH3-only protein BIM plays a critical role in initiating apoptotic pathway in multiple cell types by binding and repressing the function of several prosurvival BCL-2 family members /Chipuk and Green 2008; Youle and Strasser 2008; Czabotar et al. 2014), and is involved in craniofacial development (Grabow et al. 2018). Consistent with a role for cell survival in the etiology of craniofacial defects, we found that $\mathrm{Fgfr}{ }^{\mathrm{cKO} / \mathrm{cKO}} ; \mathrm{Fgfr}^{+/ \mathrm{cKO}} ; \mathrm{Bim}^{+/-} \mathrm{E} 17.5$ mutants exhibited a $55 \%$ reduction in midline separation along with a partial rescue of medial skeletal structures, including the anterior nasal cartilage, palatine process, premaxilla, primary and secondary palate, pterygoid process, and basisphenoid bone, compared with control embryos (Fig. 2E). The reduction in Bim levels significantly rescued defects and cell death, particularly at the level of the nasal mesenchyme and the midface (Fig. 2F,G). Taken together, these results underscore the importance of cell death in the conditional double null mutant phenotype.

\section{An allelic series of Fgfr2 signaling mutations}

To interrogate signaling mechanisms in vivo, we generated an allelic series of knock-in point mutations at the Fgfr2 locus preventing binding of effectors to the receptor (Fig. 3A,B; Supplemental Fig. S3A-C), similar to previous Fgfr1 mutations (Brewer et al. 2015). The Fgfr2 ${ }^{F}, F_{g f r 2^{C}}$, and $F g f r 2^{P G}$ mutations were designed to disrupt binding of FRS2, CRK-L, and PLC $\gamma /$ GRB14, respectively. We also generated compound Fgfr2 ${ }^{C P G}$ and Fgfr2 ${ }^{F C P G}$ signaling mutants by combining multiple signaling mutations. To validate the disruption of effector binding, 3T3 cells were transfected with triple FLAG-tagged cDNAs of FGFR2c isoforms for each signaling mutant. We confirmed disruption of FRS2, CRK-L, and PLC $\gamma$ binding in Fgfr2 ${ }^{P G}$, Fgfr2 ${ }^{C P G}, F g f r 2^{F}$, and Fgfr2 ${ }^{F C P G}$ mutations, respectively, via coimmunoprecipitation and Western blot analysis (Fig. 3B).

We first evaluated whether Fgfr2 signaling mutant alleles could partially or completely recapitulate the E10.5 Fgfr2 ${ }^{-/-}$placenta and limb phenotype (Xu et al. 1998; Yu et al. 2003; Molotkov et al. 2017). Surprisingly, all signaling allele mutants were at least partially viable and fertile as homozygotes (Supplemental Table S1). Fgfr2 ${ }^{F / F}$, Fgfr2 $2^{P G / P G}$, and Fgfr2 $2^{F C P G / F C P G}$ mutant mice exhibited a decreased growth rate compared with controls (Supplemental Fig. S4A). Interestingly, the growth retardation observed for Fgfr2 $2^{P G / P G}$ mutants was rescued by the concomitant disruption of CRK-L binding site in Fgfr2 ${ }^{C P G / C P G}$ mutants, suggesting opposite roles for these effectors in mediating FGFR2 signaling. Skeletal preparations at birth revealed a kinked tail phenotype for Fgfr2 ${ }^{P G / P G}(7 / 9)$ and Fgfr2 ${ }^{C P G / C P G}(6 / 12)$ neonates (Supplemental Fig. S4B). To further assess the effect of our signaling mutations in vivo, we crossed Fgfr2 signaling mutant mice with a null allele generated from the Fgfr2 cKO strain.

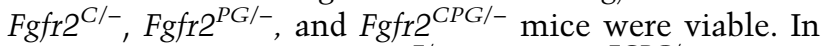
contrast, hemizygous $F g f r 2^{F /-}$ and Fgfr2 ${ }^{F C P G /-}$ mutant mice were recovered in expected Mendelian ratios at E18.5, but died at birth (Supplemental Table S1). None of the Fgfr2 ${ }^{F /-}$ and Fgfr2 ${ }^{F C P G /-}$ neonates were able to suckle, as evidenced by the absence of an abdominal milk spot, possibly as a result of cranial nerve defects since Fgfr $2^{F /-}$ and Fgfr2 ${ }^{F C P G /-}$ E10.5 mutant embryos exhibited decreased trigeminal nerve projections into facial prominences (Supplemental Fig. S4C).

Both Fgfr2 ${ }^{F / F}$ and Fgfr2 $2^{F C P G / F C P G}$ mice developed periocular lesions in the eye starting at postnatal day P15P21, associated with a defect in lacrimal gland development (Supplemental Fig. S4D,E). In mice, lacrimal gland development starts at E13.5 by an epithelial invagination into the surrounding mesenchyme, and progresses by branching morphogenesis to become a fully functional organ by P7. FGF10-FGFR2 signaling plays a critical role during this process where it regulates proliferation in epithelial cells (Steinberg et al. 2005; Garg et al. 2017). Both Fgfr2 ${ }^{F / F}$ and Fgfr2 ${ }^{F C P G / F C P G}$ mutants showed loose clusters of acinar cells, which populate the distal end of the ducts, and occupied a much smaller area at P7. A significant reduction in the size of the lacrimal gland was also brought about by reduced number of branches and smaller lengths of the tubes in the $F g f r 2^{F / F}$ and Fgfr2 ${ }^{F C P G / F C P G}$ signaling mutants (Supplemental Fig. S4F, G).

The observation that all Fgfr2 signaling mutants were viable and the fact that the Fgfr2 $2^{F C P G / F C P G}$ mutants do not recapitulate the $F g f r 2^{-/-}$phenotype raised the possibility that a critical downstream adaptor might still interact with the FGFR2 $2^{\text {FCPG }}$ receptor. We data-mined a recent proteomic screen identifying FGFR2b dependent phosphorylation events (Francavilla et al. 2013) and identified IRS2 (insulin receptor substrate) as a possible new putative FGFR2 binding partner. IRS2 belongs to the same superfamily of adaptor proteins as FRS2 and shares a similar protein architecture, with membrane targeting and PTB (phosphotyrosine binding) domains, as well as a C-terminal tail containing multiple tyrosine phosphorylation sites (Supplemental Fig. S4H). IRS2 bound weakly to both WT and FGFR2 $2^{\text {FCPG }}$ receptors in primary MEFs, independent of FGF stimulation (Supplemental Fig. S4I). However, we failed to observe a genetic interaction between $\operatorname{Irs} 2^{-/-}$and Fgfr2 $2^{F C P G / F C P G}$ mutant mice (data not shown), indicating that IRS2 is a not a critical missing effector of FGFR2 signaling in vivo. 

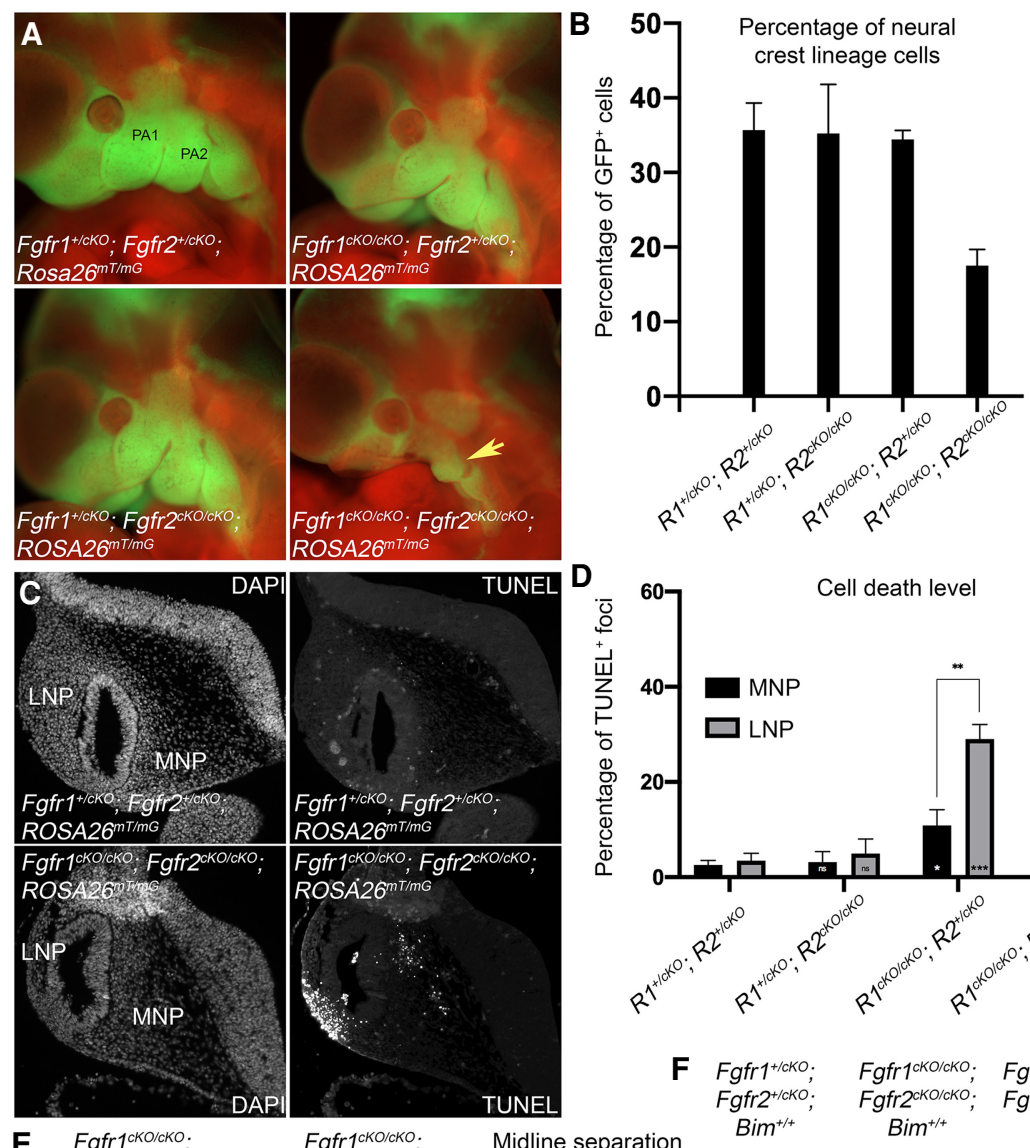

Cell death level

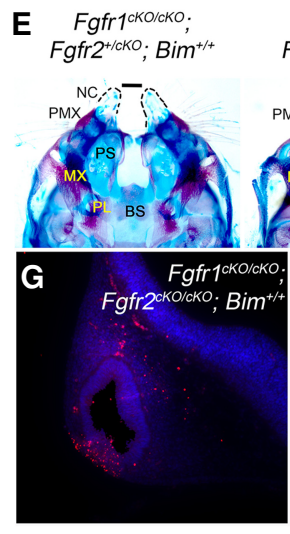

Fgfr 1 cko/cko.

Midline separation

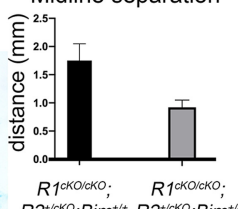

$\mathrm{R}^{+\mathrm{C} / \mathrm{KO} \cdot \mathrm{Bim}^{+/+}} \mathrm{R}^{+/ / \mathrm{KO} \mathrm{KO}} \mathrm{Bim}$
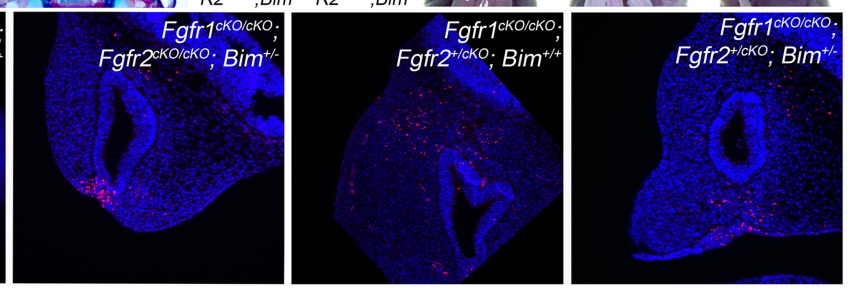

Figure 2. Craniofacial defects in double mutants are associated with cell death. (A) $\mathrm{Fg} f \mathrm{r}^{\mathrm{cKO} / \mathrm{cKO}}{ }_{;} \mathrm{Fgfr}^{\mathrm{cKO} / \mathrm{cKO}}{ }_{;} \mathrm{ROSA}_{2} 6^{\mathrm{mT} / \mathrm{mG}}$ mutants showed reduced GFP fluorescence in the PA1 (yellow arrow), PA2 and migratory stream at E10.5 suggesting reduced number of neural crest lineage cells. (B) Flow sorting was used to quantify the percentage of GFP+ cells in the facial prominences E10.5 embryo across various genotypes. The percentage of

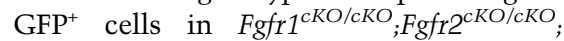
ROSA26 $6^{m T / m G}$ double mutants was reduced by half as depicted in the bar graph. The proportion of $\mathrm{GFP}^{+}$cells remain unchanged in Fgfr $1^{\text {cKO/cKO }}{ }_{;} \mathrm{Fgfr}^{+/ \mathrm{cKO}} ;$ ROSA26 $6^{\mathrm{mT} / \mathrm{mG}} \mathrm{mu}-$ tants although they exhibited observable phenotypic defects. (C) Apoptosis was examined at E10.5 by TUNEL. Increased TUNEL positive cells were observed Fgfr $1^{\text {cKO/cKO; }}$ Fgfr2 ${ }^{c K O / c K O}$ mutants in the lateral nasal process (LNP) compared with controls. Fewer TUNEL positive cells were observed in the medial nasal process (MNP). (D) Quantitation of TUNEL positive foci across different mutant genotypes show a 40-fold increase in cell death in Fgfr1/2 double mutants in the LNP /the asterisk inside the bar graph represents significance level compared with control) at E10.5. (E) Inferior view (mandibles removed) of alcian blue/alizarin red-stained mouse skulls in $\mathrm{Fgfr}^{\mathrm{cKO} / \mathrm{cKO}} ; \mathrm{Fgfr}^{+/ \mathrm{CKO}_{;}} \mathrm{Bim}^{+/+}$ and $\mathrm{Fgfr}^{\mathrm{CKO} / \mathrm{CKO}} ; \mathrm{Fgfr}^{+/ \mathrm{CKO}}{ }_{;} \mathrm{Bim}^{+/-}$embryos showed partial rescue of medial structures, the nasal cartilage $(\mathrm{NC})$ and palatine $(\mathrm{PL})$ process, premaxilla (PMX), maxilla (MX), and basisphenoid (BS) and palatal shelves (PS) in Bim ${ }^{-1+}$ mutants. The black bar measures midline separation. Average midline separation $(\mathrm{mm})$ is reduced by twofold $(N=$ 4, $\mathrm{P}=0.0109)$ in $\mathrm{Fgfr}^{\mathrm{cKO} / \mathrm{cKO}} ; \mathrm{Fgfr}^{+/ \mathrm{cKO}}$; $\mathrm{Bim}^{+/-}$as represented in the graph. $(F)$ Frontal views of control $F g f r 1^{+/ c K O} ; F_{F f r 2} / / c K O$; $\mathrm{Bim}^{+/+}, \mathrm{Fgfr}^{\mathrm{CKO} / \mathrm{cKO}} ; \mathrm{Fgfr}^{\mathrm{cKO} / \mathrm{cKO}_{;}} \mathrm{Bim}^{+/+}$, and $\mathrm{Fgfr}^{\mathrm{cKO} / \mathrm{cKO}} ; \mathrm{Fgfr}^{\mathrm{cKO} / \mathrm{cKO}} ; \mathrm{Bim}^{+/-} \mathrm{em}-$ bryos at E17.5 showing partial phenotypic rescue. The black bar indicates intercanthal distance. $(G)$ Cell death levels observed in conditional double mutants were partially rescued in $\mathrm{Bim}^{+/-}$mutants at E10.5. More $\mathrm{TUNEL}^{+}$cells were observed in the LNP in $\mathrm{Fgfr} 1^{c K O / c K O} ; \mathrm{Fgfr}^{\mathrm{cKO} / \mathrm{cKO}}$ and $\mathrm{Fgfr}^{\mathrm{cKO} / \mathrm{cKO}} ; \mathrm{Fgfr}^{c \mathrm{cKO} /+}$ mutants compared with corresponding $\mathrm{Fgfr}^{\mathrm{cKO} / \mathrm{cKO}} ; \mathrm{Fgfr}^{\mathrm{CKO} / \mathrm{cKO}} ; \mathrm{Bim}^{+/-}$and $\mathrm{Fgfr} 1^{\mathrm{cKO} / \mathrm{cKO}} ; \mathrm{Fgfr}^{\mathrm{CKO} /+} ; \mathrm{Bim}^{+/-}$counterparts.

Combined Fgfrl/2 signaling mutations do not recapitulate the null phenotypes

Because Fgfr1 and Fgfr2 are coexpressed in cNCCs, we reasoned that discrete functions of signaling pathways downstream from one receptor could be masked by the presence of the other, wild-type receptor. To test this hypothesis, we first analyzed compound conditional hemizygous Fgfr $1^{F}$ and $F g f r 1^{F C P G}$ mutations over the $F g f r 1^{c K O}$ conditional null allele and in the absence of Fgfr2. At E16.5, $\mathrm{Fgfr}^{\mathrm{F} / \mathrm{CKO}} ; \mathrm{Fgfr}^{\mathrm{cKO} / \mathrm{cKO}}$ and $\mathrm{Fgfr} 1^{\mathrm{FCPG} / \mathrm{cKO}} ; \mathrm{Fgfr}^{\mathrm{cKO} / \mathrm{cKO}}$ conditional mutants developed severe agenesis of the midface structures, but the phenotype was not as severe as in $\mathrm{Fgfr}^{\mathrm{cKO} / \mathrm{cKO}}$; $\mathrm{Fgfr}^{\mathrm{cKO} / \mathrm{cKO}}$ mutants (Fig. $3 \mathrm{C}$ ). In addition, the nasal cartilage and the mandible were more severely affected in $F g f r 1^{F C P G / c K O} ; F_{g f r}{ }^{c K O / c K O}$ conditional mutants compared with $F g f r 1^{F / c K O} ; F g f r 2^{c K O / c K O}$ conditional mutants at E16.5 and E18.5 (Fig. 3C; Supplemental Fig. S5A; Supplemental Table S2), highlighting a specific role for FGF-driven CRK and PLC $\gamma$ signaling in craniofacial development. 

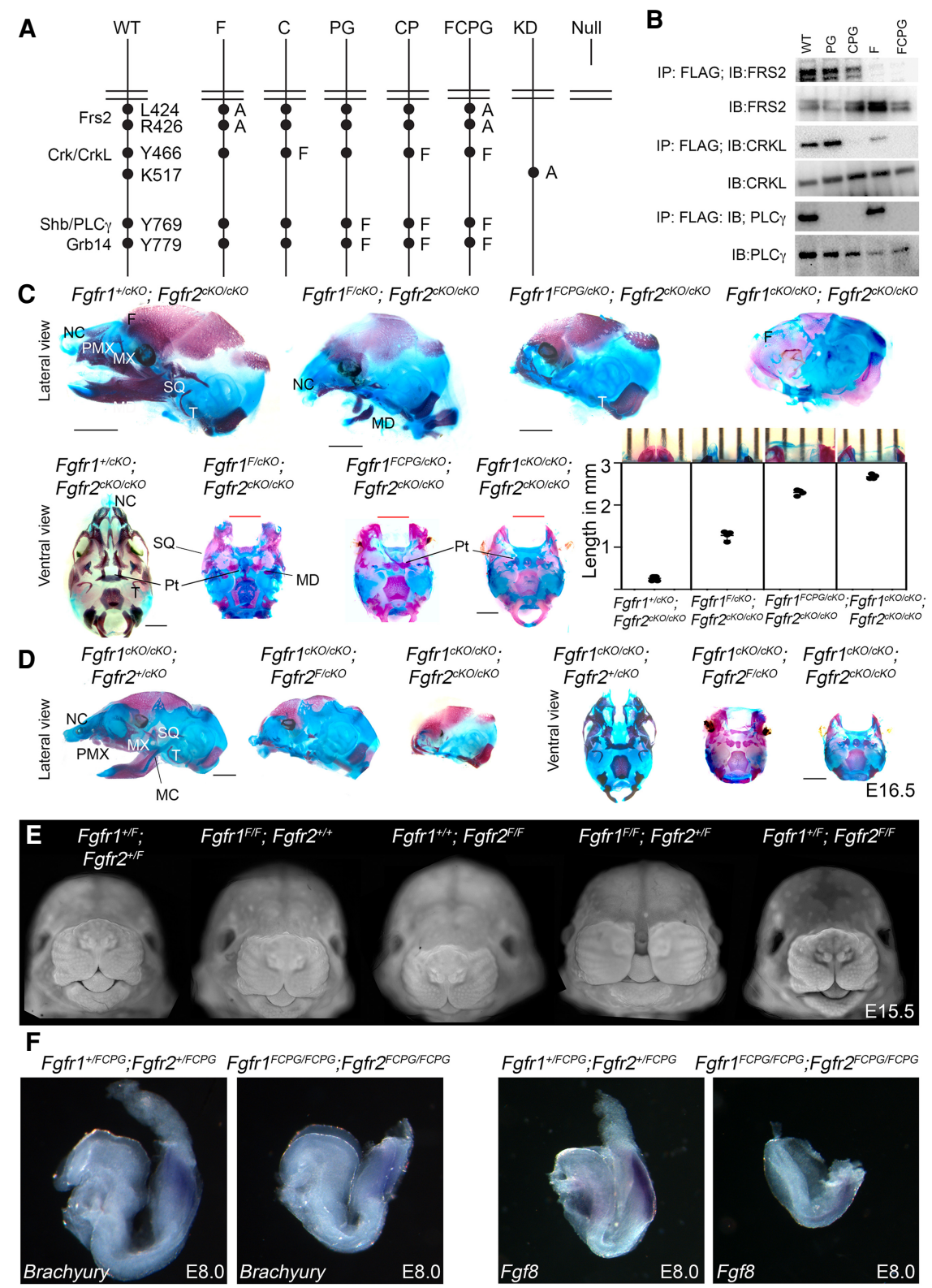

Figure 3. Coordinate effects Fgfr1 and Fgfr2 signaling mutation in development. (A) Schematic representation of the Fgfr2 allelic series. Critical effectors that bind to FGFR2 are listed at the left of the Fgfr ${ }^{W T}$ allele (WT). Critical residues for this binding are annotated at the right. Amino acid substitutions for each allele are provided to the right of all mutant alleles generated. $(B)$ Coimmunoprecipitation experiments confirmed the ability of F, C, and PG mutations to disrupt FRS2, CRKL, and PLC $\gamma$ binding to FGFR2, respectively. Constructs expressing $F g f r 2^{W T}, F g f r 2^{P G}, F g f r 2^{C P G}, F g f r 2^{F}$, and Fgfr ${ }^{F C P G}$ triple-FLAG tag cDNA were overexpressed in 3T3 cells. FLAG pull-downs were then immunoblotted to show interactions of FRS2, CRKL, and PLC $\gamma$ to FGFR2 ${ }^{\text {WT }}$ and mutant receptors. $(C)$ Sagittal and ventral views of E16.5 alcian blue/ alizarin red-stained skulls of $F g f r 1$ signaling mutants. In Fgfr1 ${ }^{F / c K O} ; \mathrm{Fgfr} 2^{\text {CKO/cKO }}$ mutants, the frontal bone $(\mathrm{F})$, nasal cartilage (NC), squamosal bone (SQ), tympanic bulla $(\mathrm{T})$, maxilla $(\mathrm{MX})$, pterygoid $(\mathrm{Pt})$, and mandible (MD) were affected. Defects in mandible, squamosal, and pterygoid bones were exacerbated in $\mathrm{Fgfr}^{\mathrm{FCPG} / \mathrm{cKO}} ; \mathrm{Fgfr2} \mathrm{CHO}^{\mathrm{cKO} / \mathrm{cKO}}$ mutants. Most severe defects were observed in $\mathrm{Fgfr} 1^{\mathrm{cKO} / \mathrm{cKO}} ; \mathrm{Fg} f \mathrm{r} 2^{\mathrm{cKO} / \mathrm{cKO}}$-null mutants, where we observed a reduction in alizarin red staining, reduction of mandible, loss of nasal cartilage, and a wider mid-facial clefting (depicted by red bars). Midfacial clefting was quantified (in millimeters) across various genotypes for signaling mutants and is represented in the graph. Scale bar, $1 \mathrm{~mm}$. (D) Sagittal and ventral views of E16.5 alcian blue/alizarin red-stained skulls of Fgfr $1^{c K O / c K O} ; F_{f g r} 2^{F / c K O}$ signaling mutants compared with $\mathrm{Fgfr} 1^{\mathrm{cKO} / \mathrm{cKO}} ; \mathrm{Fgfr}^{+/ \mathrm{cKO}} \mathrm{mu}-$ tants and $\mathrm{Fgfr}^{\mathrm{CKO} / \mathrm{CKO}} ; \mathrm{Fg} f \mathrm{r} \mathrm{C}^{\mathrm{CKO} / \mathrm{cKO}}$ double mutants. Fgfr $1^{\mathrm{CKO} / \mathrm{cKO}} ; \mathrm{Fgfr} 2^{\mathrm{F} / \mathrm{cKO}}$ signaling mutants showed striking defects in the mandible along with reduced ossification of the premaxilla (PMX) and maxilla, and loss of the squamosal bone and tympanic bulla. Defects were more severe in $\mathrm{Fgfr}^{\mathrm{cKO} / \mathrm{cKO}} ; \mathrm{Fgfr}^{\mathrm{cKO} / \mathrm{cKO}}$ double mutants. Scale bar, $1 \mathrm{~mm}$. (E) DAPI stained frontal facial view for Fgfr $1^{F}$ and $F g f r 2^{F}$ compound mutant embryos at E15.5. $\mathrm{Fgfr}^{F / F}{ }^{F g f r 2^{+/ F}}$ embryos showed a severe facial cleft compared with other genotypes. $(F)$ Brachyury $(T)$ and Fgf8 expression in Fgfr1 $1^{F C P G}$ and Fgfr2 $2^{F C P G}$ compound signaling mutants at E8.0. In contrast to Fgfr1 ${ }^{-/-}$; Fgfr2 ${ }^{-/-}$embryos, which fail to implant on the $129 S 4$ coisogenic background, we could recover Fgfr $1^{\text {FCPG/FCPG }}$;Fgfr2 ${ }^{F C P G / F C P G}$ compound mutants at E8.0 but not at E10.5. Fgfr $1^{F C P G / F C P G} ; F g f r 2^{F C P G / F C P G}$ mutants were growth-retarded and exhibit abnormal posterior development, but expressed mesodermal $\mathrm{T}$ and $\mathrm{Fg} f 8$.

We next turned to Fgfr2 signaling mutants, and analyzed their phenotype over the Fgfr ${ }^{c K O}$ conditional null allele and in the absence of $\mathrm{Fgfr} 1$. Fgfr $^{c \mathrm{cKO} / \mathrm{cKO}}{ }_{;} \mathrm{Fgfr}^{\mathrm{F} / \mathrm{cKO}}$ embryos also developed more severe midline fusion and mandible defects than $\mathrm{Fgfr}^{\mathrm{cKO} / \mathrm{cKO}}$; $\mathrm{Fgfr}^{+/ \mathrm{cKO}}$ controls. Anterior skeletal structures such as the nasal cartilage, premaxilla and maxilla, tympanic bulla, and sphenoid bones were either severely reduced or absent. A striking reduction of the mandible was observed along with a complete loss of Meckel's cartilage (Fig. 3D). We were unable to perform conditional mutagenesis with the $F g f r 2^{F C P G}$ allele as multiple lox sites were retained during the generation of this allele.

Similar to $\mathrm{Fgfr}^{\mathrm{cKO} / \mathrm{cKO}} ; \mathrm{Fgfr}^{\mathrm{cKO} / \mathrm{cKO}}$ mutants, morphological defects in $F g f r 1^{F / c K O} ; F g f r 2^{c K O / c K O}$ and

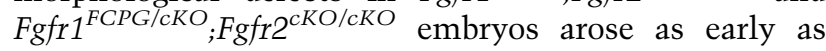
E10.5 and were accompanied by cell death in the LNP (Supplemental Fig. S5B-E). Fgfr $1^{F C P G / c K O} ; F_{f f r}{ }^{c K O} / c K O$ embryos and, to a lesser extent, $\mathrm{Fgfr}^{\mathrm{F} / \mathrm{CKO}} ; \mathrm{Fgfr} 2^{\mathrm{CKO} / \mathrm{cKO}}$ embryos developed hypoplastic nasal prominences 
(Supplemental Fig. S5B,C, yellow arrow) and mandibular prominences (Supplemental Fig. S5B,C, red arrow) along with a midfacial cleft (Supplemental Fig. S5B,C, yellow asterisk). In all these cases, non-neural crest-derived structures such as the parietal, interparietal, and supraoccipital bones remained unaffected.

Since we observed that the phenotypes of signaling mutants in cNCCs were enhanced by loss of the other receptor, we wondered whether this was generally true in the embryo at the level of each signaling mutation. Therefore, we next examined the importance of coordinate engagement of signaling pathways by both receptors upon ligand activation, throughout all stages of development. Fgfr $1^{C / C} ; \mathrm{Fgfr} 2^{C / C}$ and Fgfr1 ${ }^{C P G / C P G} ; \mathrm{Fgfr2}{ }^{C P G / C P G}$ double mutants were recovered in normal numbers, fertile, and did not exhibit a craniofacial phenotype. Compound $F_{\text {Ffrr }}{ }^{F / F} ; F \mathrm{Ffr}^{+/ F}$ mutants displayed hypoplastic nasal prominences and midline fusion defects at E15.5 with no defect in mandibular development (Fig. 3E). At E10.5, $\mathrm{Fgfr}{ }^{F /-}{ } \mathrm{Fgfr} 2^{F /-}$ compound mutants showed growth retardation compared with $\mathrm{Fgfr}^{+/ F} \mathrm{Fgfr}^{+/ F}$ mutant embryos (Supplemental Fig. S5F, red arrow). Fgfr1 ${ }^{F / F} ; F g f r 2^{F / F}$ mutant embryos were not recovered at E10.5. Similar hypoplastic nasal and mandibular prominence defects were observed in Fgfr $^{\text {FCPG/FCPG }} ;$ Fgfr $^{+/ F C P G}$ compound mutants (Supplemental Fig. S5G). Interestingly, Fgfr $1^{F C P G / F C P G} ;$ Fgfr2 ${ }^{F C P G / F C P G}$ mutants survived to E8.0 and still formed mesoderm, as evidenced by $T$ and $F g f 8$ staining (Fig. 3F), in contrast to $\mathrm{Fgfr}^{-/-} \mathrm{Fgfr2}^{-/-}$doublenull mutants, which fail at implantation (E5.5) on the same genetic background (Kurowski et al. 2019). These results indicate that signaling mutations in both Fgfr1 and Fgfr2 interact genetically during development, but that the combination of the most severe signaling mutations fails to recapitulate the double null mutant phenotype.

\section{Fgfr1/2 signaling mutations abrogate signal transduction cascades}

FGFs activate numerous signaling pathways upon ligand stimulation (Brewer et al. 2016). To evaluate intracellular pathway activation downstream of wild-type FGFR2, ${ }_{\text {FGFR2 }}{ }^{\mathrm{F}}$, FGFR2 ${ }^{\mathrm{CPG}}$, and FGFR2 ${ }^{\mathrm{FCPG}}$, we generated immortalized E10.5 frontonasal prominence cell lines (iFNPs) by crossing to Ink $4 a /$ Arf mutants. Similar to a previous study with palatal mesenchymal cells (Fantauzzo and Soriano 2017), we found that expression of facial mesenchyme markers was similar between primary and immortalized FNP cells (iFNPs) (Supplemental Fig. S6A). These cells express predominantly Fgfr1 and to a lesser extent Fgfr2, but no Fgfr3 or Fgfr4 (Supplemental Fig. S6B). We then eliminated Fgfr1 expression by CRISPR/Cas 9 mutagenesis leaving FGFR2 as the sole receptor, and interrogated activation by FGF1, which gave more robust responses than FGF8b (Supplemental Fig. S6C), of four pivotal FGF-engaged pathways (ERK1/2, PI3K/AKT, PLC $\gamma$, and STAT3) and two less well-characterized pathways (P38 and JNK) (Brewer et al. 2016). For ERK1/2, but also for PI3K/AKT and PLC $\gamma$, robust activation seen in WT iFNPs was diminished in both $F g f r 2^{F / F}$ or $F g f r 2^{C P G / C P G}$
iFNPs, but only eliminated in Fgfr2 ${ }^{F C P G / F C P G}$ mutant cells (Fig. 4A). Our results thus indicate that both FRS2 and $\mathrm{CRKL} / \mathrm{PLC} \gamma$ binding is necessary for activation of these pathways, as for Fgfr 1 (Brewer et al. 2015). STAT3, P38, and JNK activation were also abrogated in Fgfr2 ${ }^{F C P G / F C P G}$ iFNPs, with variable effects in Fgfr2 ${ }^{F / F}$ iFNPs and Fgfr2 ${ }^{C P G / C P G}$ iFNPs (Supplemental Fig. S7A).

We next revisited cell signaling pathways in Fgfr $1^{\text {FCPG/FCPG }}$ mutants (Brewer et al. 2015). We used CRISPR/Cas9 to create Fgfr $1^{\text {FCPG/FCPG }}$ Fgfr2 $2^{C R I S P R-K O}$ iFNP cells, and found that ERK1/2, pAKT, and PLC $\gamma$ activation were eliminated in these cells (Fig. 4B). Fgfr $1^{F C P G / F C P G} ;$ Fgfr2 ${ }^{C R I S P R-K O}$ iFNP cells also showed abrogation of pSTAT3 activation. Interestingly, P38 activation and JNK activation were only modestly affected (Supplemental Fig. S7B). Nonetheless, taken together, these results indicate that the most severe signaling mutation combinations in Fgfr1 and Fgfr2 broadly abrogate classic signal transduction pathways for each receptor.

\section{Fgfr2 function requires its kinase activity}

The lack of more severe phenotypes in Fgfr2 signaling mutants raised the possibility that FGFR2 acts independent of kinase activity. To address this question, we generated a K517A kinase dead (KD) mutation in the ATP binding site at the Fgfr2 locus (Fig. 3A; Supplemental Fig. S3A,B, D; Hanks et al. 1988; Bellot et al. 1991). Fgfr ${ }^{+/ K D}$ heterozygous embryos $(27 / 60)$ showed no obvious defects at E10.5. Fgfr $2^{+/ K D}$ heterozygotes appeared normal during later developmental stages up to $\mathrm{PO}$, but fewer than expected $(24 / 78)$ were recovered after weaning. They exhibited no limb or craniofacial abnormalities, but significantly more severe semidominant defects in lacrimal gland development than Fgfr2 $2^{F / F}$ and Fgfr2 ${ }^{F C P G / F C P G}$ mutants by P15 (Supplemental Fig. S4D-F).

No Fgfr $2^{K D / K D}$ homozygotes were recovered at birth (Supplemental Table S1). Morphological examination of Fgfr2 ${ }^{K D / K D}$ embryos at E10.5 showed characteristic Fgfr2 ${ }^{-/}$phenotypes, with absence of limb buds, incomplete connection of the allantois to the ectoplacental cone, and dilated pericardium (Fig. 5A), suggesting that FGFR2 broadly operates in a kinase-dependent fashion. Moreover, since the Fgfr2b constitutive mutation leads to similar limb phenotypes but no placental insufficiency (De Moerlooze et al. 2000), and phenotypes in both tissues are observed in $\mathrm{Fgfr}^{-/-}$or Fgfr2 ${ }^{K D / K D}$ mutants, FGFR2 activity must be kinase-dependent in both mesenchymal and epithelial contexts. However, $F g f r 2^{K D / K D}$ embryos exhibited additional phenotypes including severe posterior truncations and craniofacial defects (Fig. 5A). We tested for complementation between $F g f r 2^{K D}$ and $\mathrm{Fgfr}^{-}$alleles to evaluate phenotypic differences. Fgfr $2^{K D /-}$ embryos showed absence of limb buds and defects in the chorio-allantoic junction, along with a dilated pericardium, similar to $\mathrm{Fgfr}^{-/-}$embryos, and posterior truncations defects similar to $F g f r 2^{K D / K D}$ embryos (Fig. 5A). In contrast, defects in the forebrain, medial and lateral nasal prominences, and maxillary and mandibular prominences appeared less severe than in Fgfr ${ }^{K D / K D}$ mutants (Fig. 5B-D). 
Ray et al.

A

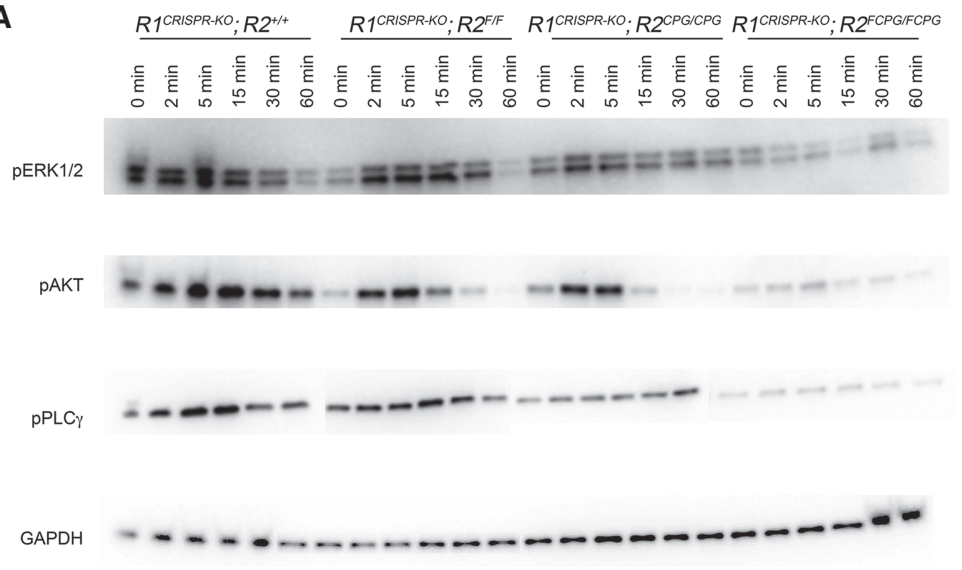

B

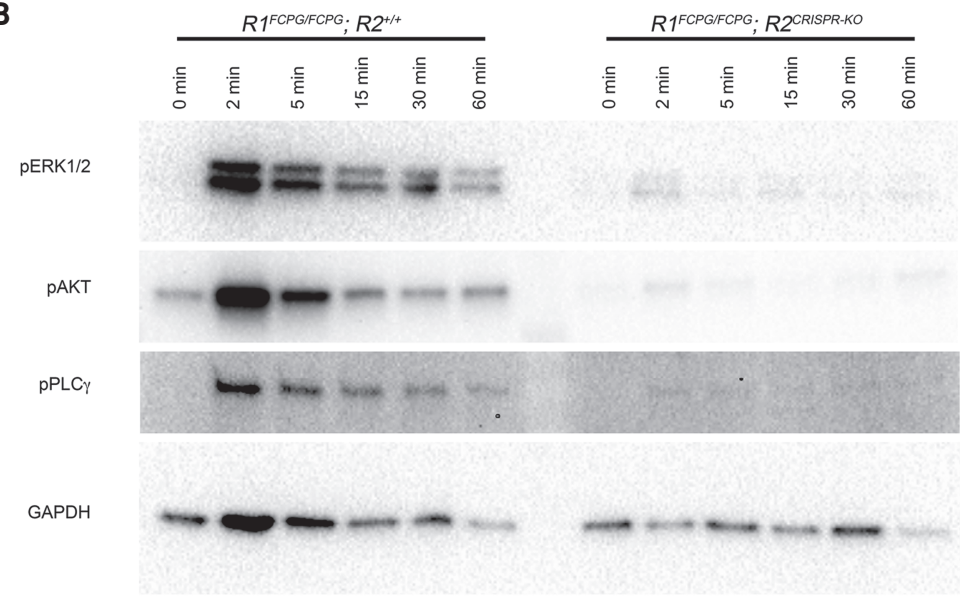

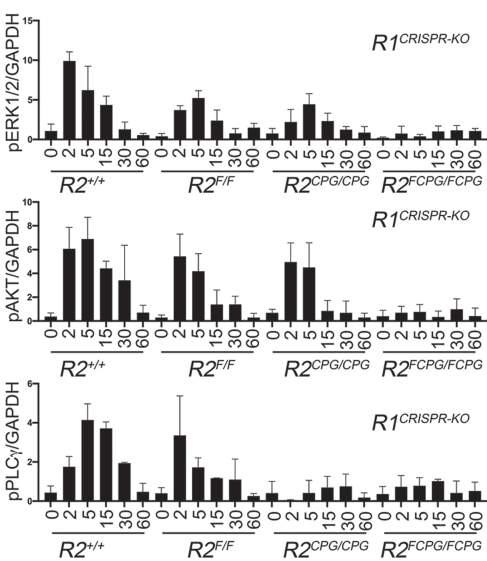

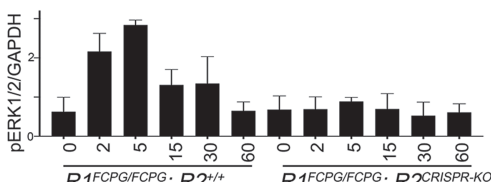
$\frac{\tau 1^{F C P G / F C P G} ; R 2^{+/+}}{R 1^{F C P G / F C P G} ; R 2^{C R I S P R-K O}}$

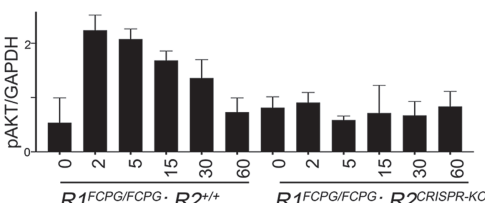

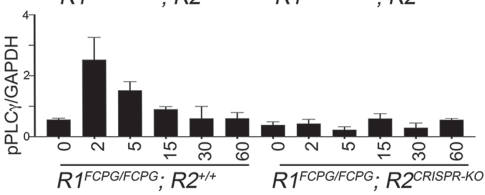

Figure 4. FGFR2 signaling outputs upon FGF1 stimulation. (A) Fgfr $1^{C R I S P R-K O}$ iFNP cells derived from the indicated genotypes, $F g f r 2^{+/+}$ $\left(R 2^{+/+}\right), F g f r 2^{F / F}\left(R 2^{F / F}\right), F g f r 2^{C P G / C P G}\left(R 2^{C P G / C P G}\right)$, and $F g f r 2^{F C P G / F C P G}\left(R 2^{F C P G / F C P G}\right)$. Cells were serum starved overnight and stimulated with $50 \mathrm{ng} / \mathrm{mL}$ FGF1 and $5 \mu \mathrm{g} / \mathrm{mL}$ heparin for the indicated times (0-60 min). Activation of pERK1/2, pAKT, and pPLC $\gamma$ was investigated by Western blots. Phospho-blots were stripped and reblotted with GAPDH as a loading control (one representative example shown here, as multiple blots were analyzed). Peak pathway activation was observed between 2 and 5 min for pERK1/2, pAKT, and pPLC $\gamma$. Fgfr $1^{C R I S P R-K O}$-null $R 2^{F C P G / F C P G}$ mutant cells eliminated activation of all three intracellular pathways. Quantification of pathway activation for $\mathrm{pERK} 1 / 2$, $\mathrm{pAKT}$, and $\mathrm{pPLC} \gamma$ normalized to GAPDH, is reported as mean \pm standard deviation with a minimum of three indepen-

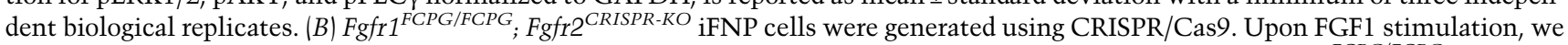
observed peak activation of phospho-ERK1/2, phospho-AKT, and phospho-PLC $\gamma$ between 2 and 5 min in control Fgfr $1^{F C P G / F C P G}$ iFNP cells by Western blot. Fgfr $1^{F C P G / F C P G}$; Fgfr2 ${ }^{C R I S P R-K O}$ iFNP cells showed no activation of these three intracellular pathways. Quantification of pathway activation for $\mathrm{pERK} 1 / 2$, $\mathrm{pAKT}$, and $\mathrm{pPLC} \gamma$ normalized to GAPDH is reported as mean \pm standard deviation with a minimum of three independent biological replicates.

The semidominant effects in $F g f r 2^{+/ K D}$ heterozygous mutants during postnatal development in the lacrimal gland, and more severe phenotypes in Fgfr2 ${ }^{K D / K D}$ mutants relative to the null affecting craniofacial and mesoderm development might be due to the ability for FGFRs to form heterodimers (Bellot et al. 1991; Ueno et al. 1992), although these have never been demonstrated in vivo in the absence of over-expression. The semidominant effects that we observed suggest that the $F g f r 2^{K D}$ allele not only inactivates Fgfr2 but also suppresses Fgfr1 activity through FGFR2 ${ }^{\mathrm{KD}}$ :FGFR1 heterodimers, wherever they are coexpressed. This would explain why $\mathrm{Fgfr} 2^{K D}$ mutants still generally resemble $\mathrm{Fgfr2}^{-/-}$mutants, which are lethal at a similar stage, rather than Fgfr $1^{-/-}$mutants (Brewer et al. 2015; Molotkov et al. 2017; Kurowski et al. 2019). While signaling might occur through heterodimers, this mechanism cannot fully account for the discrepancy between FCPG and null phenotypes for either receptor, as Fgfr ${ }^{F C P G / F C P G}$; Fgfr2 ${ }^{F C P G / F C P G}$ double mutants develop until E8.0 with a significant degree of mesoderm formation, whereas Fgfr1;Fgfr2 double null mutants have a more severe defect at implantation (Molotkov et al. 2017; Kurowski et al. 2019). Alternatively, the FGFR2 ${ }^{\mathrm{KD}}$ receptor could act as a dominant negative by titrating/ sequestering ligand away from functional receptors, if it is distributed differently in the cell, but this is unlikely as $F g f r 2^{+/ F C P G}$ mutants do not show dominant- 


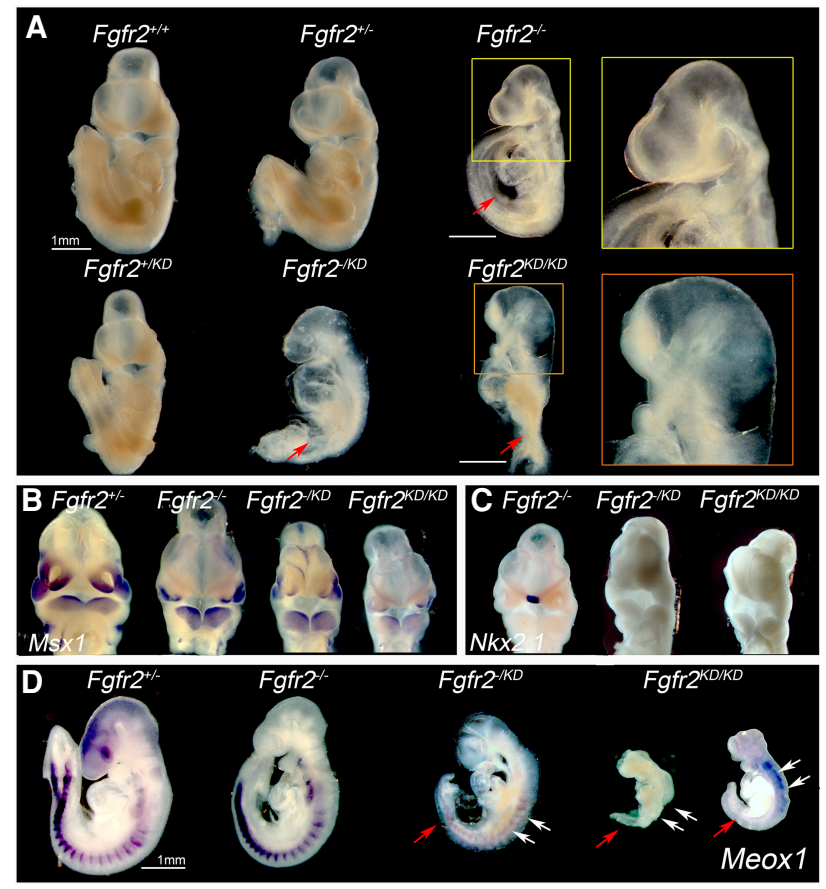

Figure 5. A kinase dead mutation in Fgfr2 recapitulates multiple aspects of the $\mathrm{Fgfr}^{-/-}$phenotype. (A) Morphological examination of Fgfr2 kinase dead phenotype at E10.5. Fgfr2 ${ }^{K D /-}$ and Fgfr2 ${ }^{K D / K D}$ mutants had no limb buds (red arrows), and had defects in the allantois, which was loosely or incompletely held by the chorion to the ectoplacental cone, along with a dilated pericardium similar to $\mathrm{Fgfr}^{-/-}$mutants. Both $\mathrm{Fgfr} \mathrm{K}^{\mathrm{KD} /-}$ and Fgfr2 ${ }^{K D / K D}$ mutants displayed severe posterior truncations and Fgfr2 ${ }^{K D / K D}$ mutants showed a more severe phenotype. Fgfr2 ${ }^{K D / K D}$ mutants also displayed craniofacial defects with poorly developed facial prominences compared with $F g f r 2^{K D /-}$ mutants. (B) Wholemount mRNA in situ hybridization for cNCC mesenchyme marker Msx1 at E10.5. Msx1 was expressed in the facial prominences (LNP, MNP, and mandibular prominences) in $\mathrm{Fgfr}^{-/-} \mathrm{em}$ bryos at similar levels to control $\mathrm{Fgfr}^{+/-}$embryos. Msx1 expression was also observed in $\mathrm{Fg} f \mathrm{r}^{\mathrm{KD/} /-}$ mutants but was reduced in $F g f r 2^{K D / K D}$ mutants. (C) Whole-mount mRNA in situ hybridization for midline marker $N k x 2.1$. $N k x 2.1$ was expressed in the midline floor plate of $\mathrm{Fgfr}^{-/-}$mutants, but not detected in Fgfr2 ${ }^{K D /-}$ and $F g f r 2^{K D / K D}$ mutants. (D) Meox1 mRNA expression in somites of E10.5 $\mathrm{Fgfr}^{+/-}$embryos was comparable with $\mathrm{Fgfr}^{-/-}$mutants, but severely reduced in both $\mathrm{Fgfr} \mathrm{KD}^{\mathrm{KD}-}$ and Fgfr2 ${ }^{K D / K D}$ mutants (white arrows) along with defects in axis elongation and posterior somite formation (red arrow).

negative effects and both knock-in alleles should be expressed at similar levels.

\section{Cell matrix and cell adhesion properties are retained beyond canonical signaling}

Since signaling mutant cells showed near complete inactivation of classic RTK signaling activities, but the corresponding mutant mice failed to recapitulate the null mutant phenotype, we reasoned that some function engaged by FGF signaling must be retained in the most severe FCPG mutants. Previous lines of evidence have im- plicated FGF signaling in the control of cell-matrix (Meyer et al. 2012) or cell-cell adhesion (Rasouli et al. 2018; Sun and Stathopoulos 2018; Kurowski et al. 2019|. We first examined Fgfr1;Fgfr2-dependent cell spreading/migration on extracellular matrix across a wound, using primary $\mathrm{Fgfr}^{+/ c K O} ; \mathrm{Fgfr2}^{+/ c K O}, \quad \mathrm{Fgfr} 1^{\mathrm{FCPG} / \mathrm{cKO}} ; \mathrm{Fgfr} 2^{\mathrm{cKO} / c K O}$, or Fgfr $1^{\text {cKO/cKO }} ; \mathrm{Fgfr}^{\mathrm{cKO} / \mathrm{cKO}} \mathrm{FNP}$ cells upon growth factor stimulation. Spreading of control cells over the wound over $12 \mathrm{~h}$ was comparable upon FGF-, PDGF-, and serum-stimulated conditions. Interestingly, Fgfr $1^{F C P G / c K O}$; Fgfr2 ${ }^{c K O / c K O}$ cells showed comparable spreading capacities in all three stimulation conditions. However, $F g f r 1^{\text {cKO/cKO; }}$ Fgfr2 ${ }^{c K O / c K O}$ double-mutant cells failed to spread into the wound area in response to FGF, while responses to PDGF and serum were normal (Fig. 6A).

Defects in migration arise from impaired focal adhesion formation during cell spreading and cell-matrix interaction. However, it is unclear what role FGF signaling plays during this process. We first investigated the role of FGFR1 in focal adhesion formation by looking at Paxillin localization by immunofluorescence as cells spread

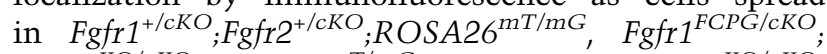

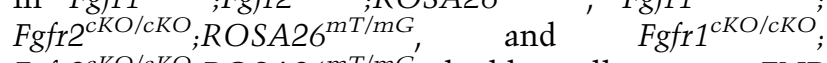
Fgfr2 ${ }^{\text {CKO/cKO }}$; ROSA2 $6^{\mathrm{mT} / \mathrm{mG}^{\prime}}$ double null mutant FNP cells upon treatment with FGF, PDGF, or serum over a 3-h period. Both $\mathrm{GFP}^{+} \mathrm{Fgfr}^{+/ c K O} ; \mathrm{Fgfr}^{+/ c K O}$; ROSA26 $6^{\mathrm{mT/mG}}$ control cells and Fgfr1 ${ }^{\text {FCPG/cKO; }}$ Fgfr2 ${ }^{\text {CKO/cKO }}$; ROSA26 ${ }^{\mathrm{mT} / m G}$ mutant cells formed numerous Paxillin-enriched focal adhesions during PDGF- and FGF-stimulated cell spreading that resembled serum-enriched conditions. Double null mutant cells, however, failed to form any Paxillin ${ }^{+}$foci upon FGF treatment and subsequent cell spreading, but still responded normally to PDGF and serum (Fig. 6B; Supplemental Fig. S8A). Western blot analysis showed reduced pFAK and total Paxillin levels in Fgfr $1^{\text {cKO/cKO }} ; \mathrm{Fg} f \mathrm{r}^{\mathrm{cKO} / \mathrm{cKO}}$ cells compared with $\mathrm{Fgfr}^{+/ c K O} ; \mathrm{Fgfr}^{+/ c K O}$ or $\mathrm{Fgfr}^{\mathrm{FCPG} / \mathrm{cKO} \text {; }}$ Fgfr2 ${ }^{c K O / c K O}$ cells, and FAK phosphorylation depended on FGF (Supplemental Fig. S8B,C).

Next, we analyzed the role of FGFR2 in cell-matrix adhesion by analyzing Fgfr1 ${ }^{\text {CRISPR-KO }}{ }_{;} \mathrm{Fgr2}^{+/+}$and Fgfr $1^{\text {CRISPR-KO }}$;Fgfr2 ${ }^{\text {FCPG/FCPG }}$ iFNP cells and found that they spread and formed Paxillin ${ }^{+}$focal adhesions in response to serum, PDGF, or FGF, in contrast to Fgfr ${ }^{\text {CRISPR-KO }}$; Fgfr2 ${ }^{-/-}$iFNP cells (Fig. 6C; Supplemental Fig. S8D). Because FGFR2 broadly acts in a kinase-dependent fashion, we next tested the behavior of Fgfr $1^{\text {CRISPR-KO }} ; \mathrm{Fgfr} 2^{K D / K D}$ iFNP cells and found that they failed to spread and form focal adhesions in response to FGF1, but responded normally to PDGF or serum (Fig. 6C; Supplemental Fig. S8D,E). We furthermore tested the effect of a pan-FGFR kinase inhibitor, Infigratinib, at various doses found to inhibit FGF induced ERK1/2 activation. We likewise observed a defect in cell spreading and focal adhesion formation in response to FGF1, but not PDGF or serum (Supplemental Fig. S8F). Taken together, these observations indicate that although FGFR $1^{\text {FCPG }}$ and FGFR $2^{\text {FCPG }}$ lose most FGF-dependent intracellular kinase signaling outputs, they still retain functions pertaining to cell-matrix interactions and that cell spreading and 


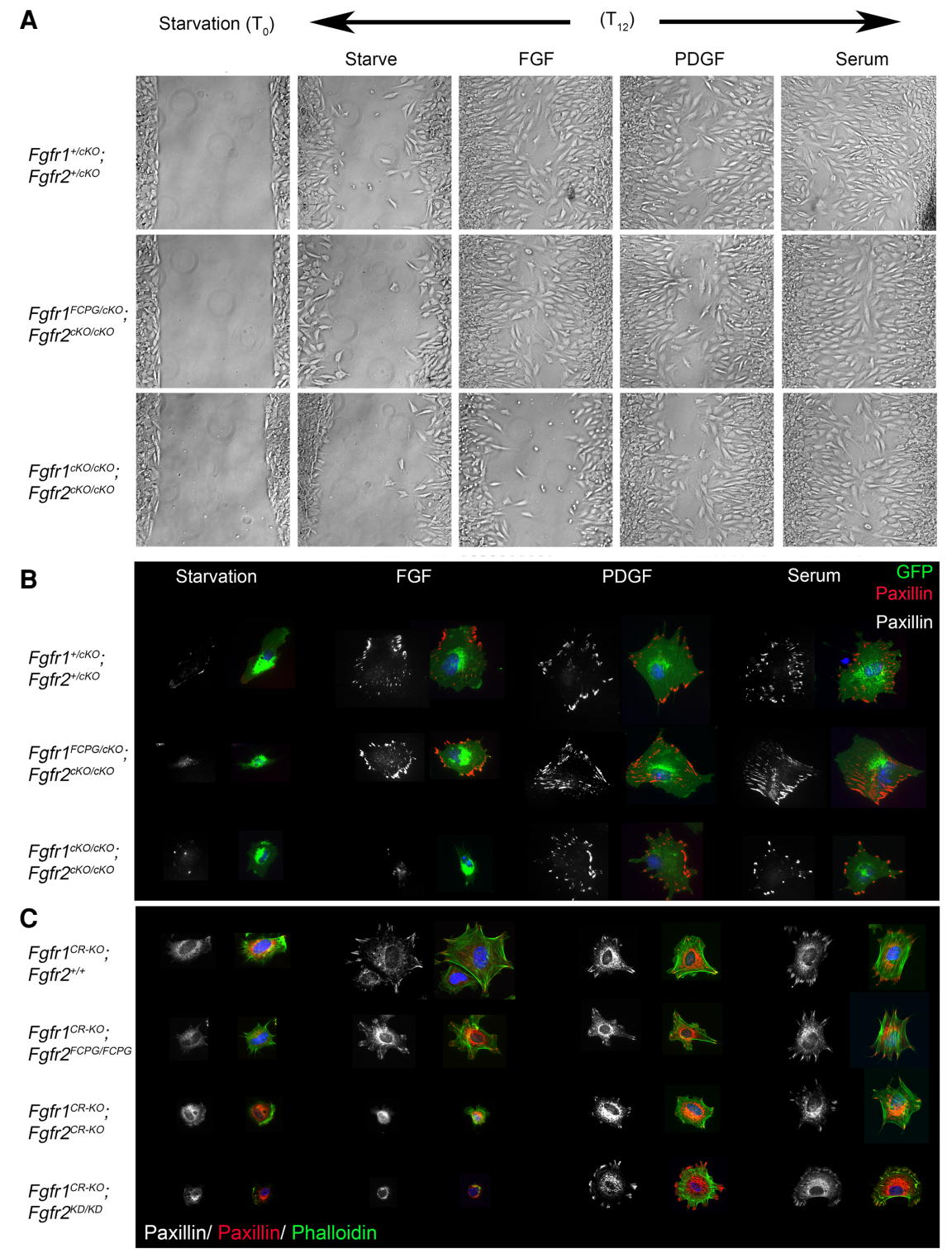

Figure 6. Cell matrix adhesion properties are retained in FCPG mutants. (A) Scratch/ wound healing assay was used to study cell spreading. Control $\left(F g f r 1^{+/ c K O} ; F_{f f r}{ }^{+/ c K O}\right)$ and $\mathrm{Fgfr}^{\mathrm{FCPG} / \mathrm{cKO}} ; \mathrm{Fgfr}^{\mathrm{cKO} / \mathrm{cKO}}$ primary FNP cells showed active spreading over 12 $\mathrm{h}\left(\mathrm{T}_{12}\right)$ in response to FGF1, PDGF-A, or serum. Fgfr $1^{c K O / c K O} ; \mathrm{Fgfr} 2^{c K O / c K O}$ mutant cells showed limited spreading upon FGF stimulation, but normal spreading in response to PDGF or serum. (B) Focal adhesion formation was assayed by Paxillin immunostaining in Fgfr1 signaling mutant primary FNP cells. $\mathrm{GFP}^{+} \quad \mathrm{Fgfr}^{+/ c K O} ; \mathrm{Fgfr}^{+/ c K O} ; \mathrm{ROSA}_{2} 6^{\mathrm{mT} / \mathrm{mG}}$ control, $\quad F g f r 1^{F C P G / C K O} ; F^{F f r 2}{ }^{+/ c K O}$; ROSA26 ${ }^{\mathrm{mT} / \mathrm{mG}}$, and $\mathrm{Fgfr} \mathrm{I}^{\mathrm{cKO} / \mathrm{cKO}} ; \mathrm{Fgfr}^{\mathrm{cKO} /}$ ${ }^{c K O} ;$ ROSA2 $6^{\mathrm{mT} / \mathrm{mG}}$ mutant cells were treated with FGF1, PDGFA or serum for $3 \mathrm{~h}$ before analyzing Paxillin localization to focal adhesions. In control cells and $F g f r 1^{F C P G / c K O} ; \mathrm{Fgfr2}^{+/ c K O}$, we detected multiple Paxillin ${ }^{+}$foci upon FGF1, PDGFA, or serum stimulation. Fgfr $1^{\mathrm{cKO} / \mathrm{cKO}} ; \mathrm{Fgfr} 2^{\mathrm{cKO} / \mathrm{cKO}} ; \mathrm{ROSA}_{2} 6^{\mathrm{mT} / \mathrm{mG}}$ mutant FNP cells failed to form focal adhesion in response to FGF, in contrast to PDGF or serum (quantified in Supplemental Fig. S8A). (C) Focal adhesion formation was assayed by Paxillin immunostaining in Fgfr2 signaling mutant primary FNP cells. Cell spreading properties were analyzed for Fgfr2 $^{+/+}$(Fgfr1 $1^{\text {CRISPR-KO }}$ Fgfr2 $\left.^{+/+}\right)$, Fgfr2 $^{\text {FCPGl }}$ FCPG (Fgfr $1^{\text {CRISPR-KO }}$;Fgfr2 ${ }^{\text {FCPG/FCPG }}$ ), Fgfr2 ${ }^{-1}$ - $\left(\right.$ Fgfr $\left.1^{C R-K O} ; F g f r 2^{C R-K O}\right)$, and Fgfr2 ${ }^{K D / K D}$ $\left(\right.$ Fgfr $\left.1^{C R-K O} ; F g f r 2^{K D / K D}\right)$ iFNP cells in which Fgfr1 was disrupted. Addition of FGF1, PDGFA, or serum resulted in robust cell spreading and formation of Paxillin ${ }^{+}$focal adhesions in Fgfre $2^{F C P G / F C P G}$ and $\mathrm{Fgfr}^{+/+}$iFNP cells. Both $F g f r 2^{-/-}$and Fgfr2 $2^{K D / K D}$ iFNP cells showed severe defects in focal adhesion formation upon FGF1 treatment, but were unaffected in response to PDGFA or serum (quantified in Supplemental Fig. S8D). stabilization of cell-matrix interactions are actively governed by FGF signaling to its receptors.

We also explored whether Fgfr $1^{F C P G}$ cells freshly dissociated from the embryo established stable cell-cell contacts comparable with control cells. We found extensive adherens junctions among $\mathrm{Fgfr}^{+/ c K O} ; \mathrm{Fgfr}^{+/ c K O}$; ROSA26 $6^{\mathrm{mT} / \mathrm{mG}}$ control cells and Fgfr $1^{\text {FCPG/cKO; }}$ Fgfr2 $2^{c K O / c K O} ;$ ROSA26 $6^{\mathrm{mT} / m G}$ cells, marked by localized $\beta$-catenin along cell boundaries (Fig. 7A,B; Supplemental Fig. S8G). In contrast, double null mutant cells showed far fewer cell-cell contacts with no localized $\beta$-catenin accumulation, suggesting that contacts are either unstable or do not mature (Fig. 7A,B). Last, we examined cell-cell contacts in vivo, in the E11.5 LNP (Fig. 7C). $\mathrm{GFP}^{+} \mathrm{cNCCs}$ in the mesenchyme exhibited extensive cell-cell contacts within the LNP in both control and Fgfr $1^{F C P G / c K O}$; Fgfr2 $^{c K O / c K O} ; R^{2} O S A 26^{m T / m G}$ embryos. Strikingly, $\mathrm{GFP}^{+}$
cNCCs in the double null mutant LNP were mostly isolated and interspersed, although cell contacts in the MNP remained unaffected (Fig. 7C). Taken together, these results indicate that the most severe signaling mutations in Fgfr1 and Fgfr2 still retain cell-matrix and cell-cell interactions otherwise lost in the nulls, while abrogating classic signal transduction pathways.

\section{Discussion}

In this work, we sought to address the signaling mechanisms through which FGFs function in development. Because FGFs are known to regulate craniofacial development (Trumpp et al. 1999; Rice et al. 2004; Hosokawa et al. 2009; Griffin et al. 2013; Wang et al. 2013; Brewer et al. 2015), we used the craniofacial mesenchyme as a 
model to assess the phenotypic consequences of various disruptions in FGF signaling. First, we showed that Fgfr1;Fgfr2 conditional NCC mutants exhibit a near total lack of mandible development in addition to a midface integration defect, a phenotype considerably more severe than previously noticed (Park et al. 2008), possibly due to the 129S4 coisogenic background used throughout this study. Second, although we identified tissue-specific requirements for individual signaling pathways in craniofacial development, signaling mutants that disrupt the established signal transduction cascade do not phenocopy null mutants. Last, we demonstrated additional, noncanonical FGF signaling outputs that seemingly function independent of classic FGF signal transduction pathways.

Despite the established activity of FGFs as mitogens in many cell types, we did not detect a significant change in cell proliferation in $\mathrm{Fgfr} 1^{\mathrm{cKO} / \mathrm{cKO}} ; \mathrm{Fgfr} 2^{\mathrm{cKO} / \mathrm{cKO}}$ double null mutant embryos. However, we observed high levels of apoptosis in conditional double null mutants, suggesting that this process might be involved in establishing the overall mutant phenotype. Increased cell death has previously been observed in the branchial arches of hypomorphic or conditional Fgf8 mutants (Trumpp et al. 1999; Griffin et al. 2013). Cell death was highest in the LNP, which normally together with the maxillary prominence expand considerably and push cells toward the midline. To functionally test the role of cell death, we crossed a null mutant allele for Bim, which antagonizes anti-apoptotic members of the BCL2 family, into the double conditional null background. This resulted in decreased cell death accompanied by partial rescue of frontal structures, highlighting a critical role for FGF-mediated cell survival during craniofacial development. How FGF signaling might regulate cell survival remains to be determined, but BIM is a known target of phosphorylation by several MAP kinases, particularly ERK1/2, which phosphorylates BIM and targets it for ubiquitination and proteasomal degradation (Clybouw et al. 2012). JNK and PI3K/AKT activation are also known to affect BIM levels (Lei and Davis 2003). Cell survival through BIM may therefore be regulated by FGF since several of these signaling pathways are engaged by FGFR1 and FGFR2 (Brewer et al. 2016).

FGFs are best known for activating signal transduction cascades, most prominently ERK1/2 (Lanner and Rossant 2010; Brewer et al. 2016). Ever since the classic studies on the Sevenless receptor (Simon et al. 1991), we have expected RTK function to depend mostly on canonical signal transduction, but, surprisingly, we found that mutations in Fgfr1 and Fgfr2, which broadly eliminate such outputs, fail to recapitulate the $F g f r 1^{-/-}$or $\mathrm{Fgfr}^{-/-}$phenotypes. Interestingly, some residual P38 activation was still observed in Fgfr $1^{F C P G / F C P G} ;$ Fgfr2 ${ }^{C R I S P R-K O}$ cells. P38 may thus represent a critical FGFR1 effector in primitive endoderm (Thamodaran and Bruce 2016), which does not develop well in $\mathrm{Fgfr}^{-/-}$mutants, in contrast to FGFR $1^{F C P G / F C P G}$ embryos that survive to E10.5 (Brewer et al. 2015). The near complete abrogation of multiple signal transduction outputs in the most severe Fgfr1 and Fgfr2 signaling alleles indicates that we have interrogated relevant cell signaling pathways and implies the existence of noncanonical functions not impacted by our signaling mutations. For FGFR2 in particular, the phenotypic gap between Fgfr2 ${ }^{F C P G / F C P G}$ and $F g f r 2^{-/-}$mutant embryos could either be due to heretofore unrecognized kinase-dependent signaling activity or to a kinase-independent function. To distinguish between these possibilities, we generated an inactivating Fgfr ${ }^{K D}$ allele by introducing a mutation in the ATP binding site of the kinase domain (Hanks et al. 1988; Bellot et al. 1991). Although such kinase dead mutations have been introduced in cells or organisms ectopically, to our knowledge this is the first such knock-in allele generated in an RTK gene. This Fgfr2 mutation resulted in lethality at E10.5, with defects in limb outgrowth and chorio-allantoic junction, reminiscent of the Fgfr2 $2^{-/-}$mutant phenotype. The fact that this mutation recapitulates hallmark $F g f r 2^{-/-}$mutant phenotypes supports the model that FGFR2 broadly operates in a kinase-dependent fashion.

A wide body of literature has implicated FGFRs in cell adhesion through interactions of the extracellular domain, which remains untouched in any of our signaling mutations, with cell adhesion molecules (Williams et al. 1994; Francavilla et al. 2009). FGF ligand binding to FGFRs is known to involve a third party, heparan sulfate proteoglycans (Rapraeger et al. 1991; Yayon et al. 1991; Endo et al. 2012), which in turn can interact with integrins, regulating cell-matrix adhesion (McQuade et al. 2006; Moser et al. 2009; Geiger and Yamada 2011). Consistent with a critical role for FGFRs, we found that cell-matrix adhesion was unperturbed in cells carrying the most severe signaling mutations, but lost in the absence of FGFRs following FGF stimulation. Because FGF ligand still promotes cell-matrix adhesion in cells derived from Fgfr $1 / 2^{F C P G}$ mutants, the activity of cell adhesion receptors must be enhanced independent of traditional signaling outputs. The cell adhesion defect was also observed in Fgfr $1^{\text {CRISPR-KO }}$;Fgfr $2^{K D / K D}$ cells and in cells treated with an FGFR-specific kinase inhibitor, suggesting a possible model in which the adhesion complex is recruited by FGFR1/2 and further modified directly or indirectly by an unknown molecule/kinase. Defects in FGF-dependent adhesion could also result in the induction of anoikis (Frisch and Francis 1994), a process previously shown to be regulated by Bim (Mailleux et al. 2007), potentially linking our observed adhesion defects and increase in cell death in the LNP. Last, focal adhesion assembly and phosphorylation defects have also been observed in $\mathrm{Fgfr}^{-/-} ; \mathrm{Fgfr}^{-/-}$keratinocytes (Meyer et al. 2012), suggesting that engagement of FGF signaling has a broad function in regulating cell adhesion in both mesenchymal and epithelial contexts. The involvement of RTK signaling with cell adhesion processes might be more general, as other receptor tyrosine kinases like PDGFRs have been found to bind integrins (Borges et al. 2000), and PDGFR signaling mutations have also failed to recapitulate null mutant phenotypes (Klinghoffer et al. 2002; Tallquist et al. 2003).

Both FGFR1 and FGFR2 are also known to interact through their extracellular domain acid box with various cell adhesion molecules such as cadherins (Williams 
Ray et al.
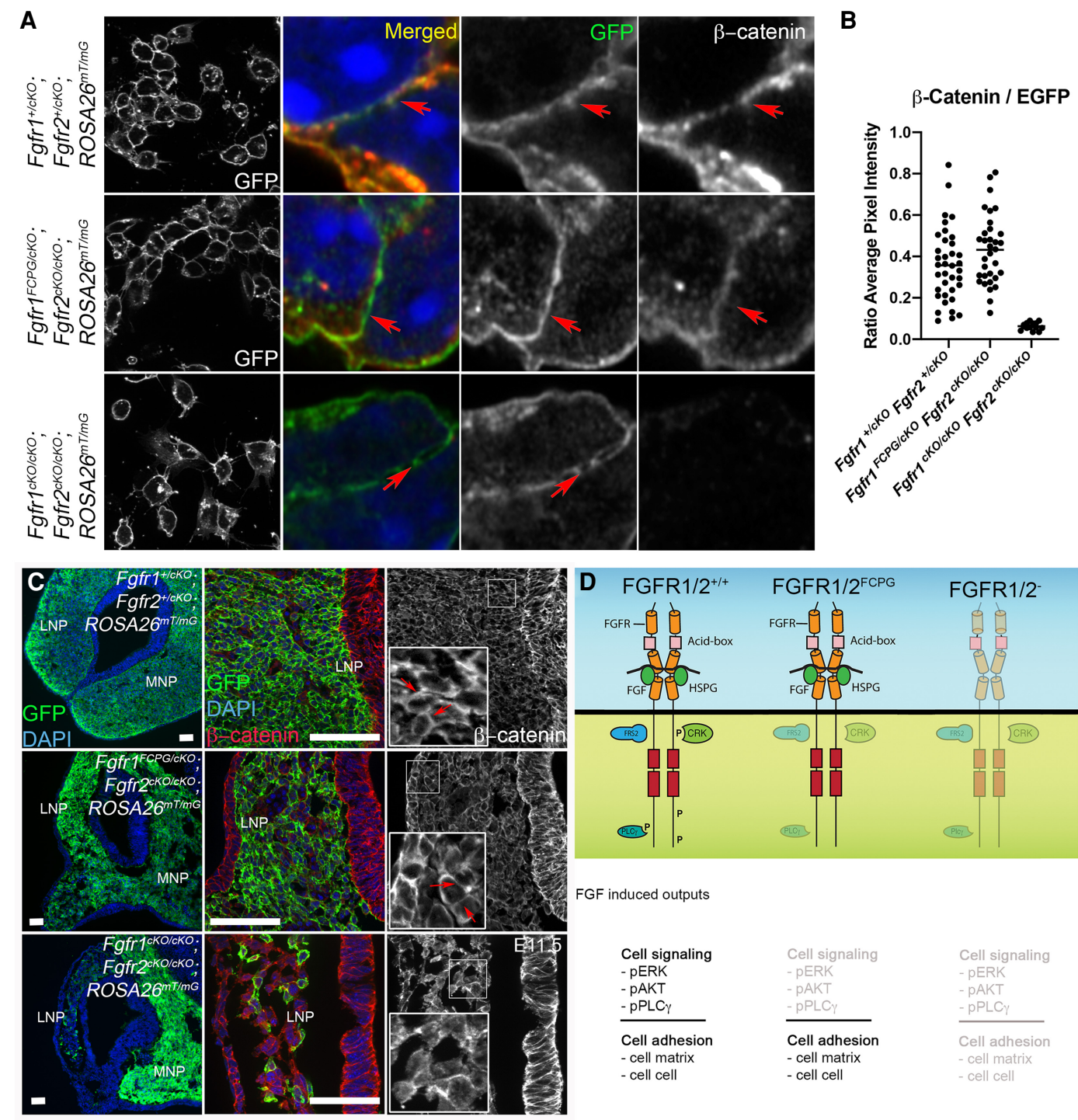

Figure 7. Cell-cell adhesion is retained in $\mathrm{Fgfr}$ signaling mutants. $(A) \mathrm{GFP}^{+}$primary FNP cells from control $\mathrm{Fgfr}^{+/ c K O} ; \mathrm{Fgfr} 2^{+/ c K O}$; ROSA26 $6^{\mathrm{mT} / \mathrm{mG}}$ and $\mathrm{Fgfr} 1^{\mathrm{FCPG} / \mathrm{cKO}} ; \mathrm{Fgfr} \mathrm{2}^{\mathrm{cKO} / \mathrm{cKO}} ; \mathrm{ROSA}_{2} 6^{\mathrm{mT} / \mathrm{mG}}$ embryos formed extensive cell-cell contacts, in contrast to $\mathrm{Fgfr} 1^{\mathrm{cKO} / \mathrm{cKO}} ; \mathrm{Fgfr}^{c \mathrm{CKO} / \mathrm{cKO}} ;{ }_{;} \mathrm{ROSA} 26^{\mathrm{mT} / \mathrm{mG}}$ mutants. Quantification of cell contacts is provided in Supplemental Figure S8G. $\beta$-Catenin was localized along the cell contact boundaries in $\mathrm{GFP}^{+} \mathrm{FNP}$ cells (red arrows) from control and $\mathrm{Fgfr} 1^{F C P G / c K O}{ }^{F g} \mathrm{Ffr}^{c K O / c K O}$; $R O S A 26^{m T / m G}$ embryos in contrast to Fgfr $1^{c K O / c K O} ; F_{f f r} 2^{c K O / c K O} ; R O S A 26^{m T / m G}$ mutants. (B) $\beta$-Catenin immunofluorescence was quantified and represented as mean for each genotype. $(C)$ Cell contacts in the $\mathrm{cNCC}$-derived mesenchyme $\left(\mathrm{GFP}^{+}\right)$were analyzed in vivo for

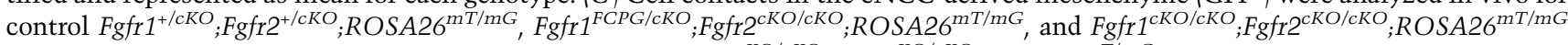
mutants. The MNP remained unaffected across genotypes. Fgfr $1^{c K O} /{ }^{c K O} ; F_{f r} 2^{c K O / c K O} ; R O S A 26^{\mathrm{mT} / m G}$ double null mutants showed defects in the LNP. Extensive cell-cell contacts (red arrows) with $\beta$-catenin localization (insets) were observed in vivo in control $\mathrm{Fgfr}^{+/ / c K O}$;

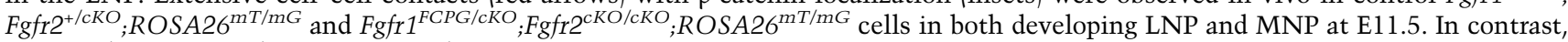
Fgfr $1^{c K O / c K O}{ }_{;} \mathrm{Fgfr}^{\mathrm{cKO} / \mathrm{cKO}}{ }_{;} \mathrm{ROSA}_{2} 6^{\mathrm{mT} / \mathrm{mG}}$ double null mutants $\mathrm{GFP}^{+}$cells remained sparse in the LNP and showed no localized $\beta$-catenin. (D) Model of FGF-mediated cell signaling pathways. In wild-type cells, activation by FGFs engages a canonical RTK signal transduction pathway, leading to the activation of ERK1/2, PI3K/AKT, PLC $\gamma$, and additional pathways. In addition, FGFs activate noncanonically both cell-matrix as well as cell-cell adhesion, in a kinase-dependent manner, possibly facilitated through interactions of the FGF receptors through their extracellular domain with cell adhesion receptors. Fgfr1 $1^{F C P G}$ or Fgfr2 ${ }^{F C P G}$ mutant cells fail to activate a classical RTK signal transduction pathway (light gray) but can still promote cell adhesion (black), as their kinase activity has not been disrupted. In null mutant cells, neither FGF-induced cell signaling nor cell adhesion are observed (light gray), since the receptors are not expressed.

et al. 1994; Kon et al. 2019), critical players in cNCC migration (Scarpa et al. 2015). Consistent with a role for FGFRs in mediating cell-cell adhesion through cadherins, we observed that cells derived from the most severe cell signaling mutants made strong $\beta$-catenin-positive cell contacts, in contrast to double null mutant cells. We also observed fewer contacts in vivo, where double null mutant cells showed very limited interactions in the 
LNP. FGF signaling regulates E-cadherin localization, and in the absence of Fgfr1, E-cadherin polarization is affected in mural trophectoderm (Kurowski et al. 2019), Drosophila mesoderm (Sun and Stathopoulos 2018), and zebrafish cardiomyocytes (Rasouli et al. 2018). FGF signaling also regulates cadherin switching during epithelial to mesenchymal transition, including neural crest cell delamination (Sun et al. 1999; Ciruna and Rossant 2001; Nieto et al. 2016). Taken together, our results indicate that FGFRs regulate cell adhesion, and possibly other processes, through mechanisms beyond their classic signaling cascades (Fig. 7D). Additional genetic, biochemical, and cell biological studies may identify further noncanonical roles for these receptors beyond their traditional activities in signal transduction.

\section{Materials and methods}

Generation of knock-in mice

Four distinct targeting vectors carrying the $\mathrm{Fgfr}^{F}, \mathrm{Fgfr}^{\mathrm{C}}$, Fgfr2 ${ }^{P G}$, and Fgfr2 ${ }^{K D}$ mutations were generated. The Fgfr2 ${ }^{F}$ targeting vector was generated by cloning a short homology arm (1.7-kb region between exons 9 and 10) and a long homology arm (5.1 kb, spanning exon 10) into PGKneolox2DTA.2 (Hoch and Soriano 2006). To allow recombineering into SW 105 bacteria, the neo cassette was subsequently replaced by PGKEm7neo flanked by FRT sites, which contain both a eukaryotic and a prokaryotic promoter. Similarly, for the $F g f r 2^{C}$ targeting vector, we cloned a long homology arm (5.3-kb region spanning exon 11) and a short homology arm (1.7-kb region between exons 11 and 12) into PGKneolox2DTA.2 and used a PGKEm7neo flanked by both FRT and LoxP sites for recombineering. For the $F g f r 2^{P G}$ targeting vector, we cloned a short homology arm $\left(1.9-\mathrm{kb}\right.$ region $5^{\prime}$ of exon 19) and a long homology arm (5.4 kb spanning exon 19 and 3'-UTR) into PGKneolox2DTA.2 and used a PGKEm7neo flanked by FRT sites for recombineering. For Fgfr ${ }^{K D}$ targeting vector, we cloned short homology arm (1.9-kb SmaI to MfeI, spanning exon 12) and a 3.7-kb-long homology arm (MfeI to BclI, spanning exon 13) into PGKneolox2DTA.2 (Hoch and Soriano 2006). Details of regions corresponding to homology arms are in Supplemental Table S3.

For all four alleles, site-directed mutagenesis (SDM) was performed using Phusion polymerase (NEB \#M0530). Nucleotide substitutions introduced by SDM in exon 10 for $F g f r 2^{F}$ allele (introduces an XmaI site), exon 11 for $\mathrm{Fgfr}^{C}{ }^{C}$ allele (introduces a SacI site), exon 19 for $\mathrm{Fgfr}^{P G}$ allele (introduces an EcoRI site) and in exon 12 for Fgfr $2^{K D}$ allele (introduces an AluI site) are provided in Supplemental Figure S3B. All introduced mutations were verified by sequencing.

The targeting vectors for Fgfr2 ${ }^{F}$ (linearized with NotI), Fgfr2 ${ }^{C}$ (linearized with XhoI), Fgfr2 ${ }^{P G}$ (linearized with NotI) and $F g f r 2^{K D}$ (linearized with NotI) were electroporated into 129S4 AK7 ES cells. For generating the allelic series of signaling mutations, ES cells were targeted first with the $\mathrm{C}$ targeting vector generating $\mathrm{Fgfr}^{+/ C}$ mutant cells. After verifying for correct targeting events, the neo cassette was removed by transient transfection with PGKCrebpA, leaving a single LoxP site behind (Supplemental Fig. S3A). Fgfr2 ${ }^{+/ C}$ ES cells were then targeted using the PG targeting vector generating either $\mathrm{Fgfr}^{+/ P G}$ or $\mathrm{Fgfr}^{+/ C P G}$ mutant cells, as determined by breeding of the chimeras to ROSA26 $6^{\text {Flpo }}$ mice (Raymond and Soriano 2010). After verifying for correct targeting events, the neo cassette was removed by transient transfection with PGKFlpobpA (Raymond and Soriano 2007), leaving both an FRT site and a LoxP site behind (Supplemental Fig. S3A). Fgfr2 ${ }^{+/ C P G}$ neo ${ }^{-}$ES cells were finally targeted with the $\mathrm{F}$ targeting vector, resulting in $\mathrm{Fgfr}^{+/ F}$ or $F g f r 2^{+/ F C P G}$ mutant ES cells, as determined by breeding. After verifying for correct targeting events, the neo cassette was removed by transient transfection with Flpe, which is less efficient than Flpo in ES cells (Raymond and Soriano 2007), in order to not recombine sequences between exons 10-18 due to the retention of the FRT site during the generation of the Fgfr2 ${ }^{P G}$ allele. We screened targeting events initially by PCR coupled with restriction digestion to identify incorporation of nucleotide substitutions. Proper targeting was confirmed by Southern blotting using $5^{\prime}$ external and $3^{\prime}$ external probes and then an internal probe against Neo. Primers used to generate probes for confirming targeted clones using Southern blots are described in Supplemental Table S4.

ES cell chimeras were bred to Meox2-Cre $\left(\mathrm{Meox} 2^{\text {tm1/Cre)Sor }}\right)$ or ROSA26Flpo (Gt(ROSA)26Sor $\left.{ }^{\text {tm2(FLP }}{ }^{*}\right)$ Sor $)$ deleter mice (Tallquist and Soriano 2000; Raymond and Soriano 2010) maintained on a 129S4 genetic background to remove the neomycin selection cassette and the deleter alleles were subsequently crossed out. Two independent mouse lines were generated from independent ES cell clones for each allele, and phenotypes were confirmed in both lines. The Fgfr2 ${ }^{C}, F g f r 2^{P G}, F g f r 2^{C P G}, F g f r 2^{F}, F g f r 2^{F C P G}$, and Fgfr ${ }^{K D}$ alleles were maintained on the $129 \mathrm{~S} 4$ genetic background. These six mouse lines will be available from the Mutant Mouse Regional Resource Center (MMRRC) under the following accession numbers: $068000\left(F g f r 2^{F}\right), 068001\left(F g f r 2^{C}\right), 068002$ $\left(F g f r 2^{P G}\right), 068003\left(F g f r 2^{C P G}\right), 068004\left(F g f r 2^{F C P G}\right)$, and 068005

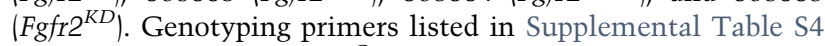
were used to identify Fgfr2 ${ }^{C}$ (WT band 553 bp; mutant band 655 bp), Fgfr2 ${ }^{P G}$ (WT band 377 bp; mutant band $611 \mathrm{bp}$ ), Fgfr2 ${ }^{F}$ (WT band $379 \mathrm{bp}$; mutant band $614 \mathrm{bp}$ ), and $F g f r 2^{K D}$ (note: PCR is followed by Alu1 restriction digestion; WT band $350 \mathrm{bp}$; mutant band $300 \mathrm{bp}$ ) alleles. The F, C, or PG primers were all able to genotype $F g f r 2^{F C P G}$ mice.

\section{Mouse strains}

All animal experimentation was conducted according to protocols approved by the Institutional Animal Care and Use Committee of the Icahn School of Medicine at Mount Sinai. Fgfr ${ }^{c K O / c K O}, F g f r 2^{c K O / c K O}, F g f r 1-G F P$, and Fgfr2-mCherry were previously described (Hoch and Soriano 2006; Molotkov et al. 2017). Fgfr1 signaling mutations (Brewer et al. 2015) are referred to as $F g f r 1^{C}, F g f r 1^{F}, F g f r 1^{C P G}$, and Fgfr $1^{F C P G}$. Tg (Wnt1-cre)11Rth, Tg(Wnt1-cre)2Sor, Cdkn2a $a^{+/ t m 1 R d p, ~ G t ~}$ (ROSA)26Sor ${ }^{\text {tm4 } 4 \text { (ACTB-tdTomato,-EGFP)Luo, }}$ Bcl2111 ${ }^{\text {tm1.1Ast }}$ and Irs $2^{\operatorname{tm} 1 M f w}$ are referred to in the text as Wnt1-Cre, Wnt1-Cre2,

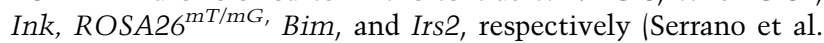
1996; Danielian et al. 1998; Withers et al. 1998; Bouillet et al. 1999; Muzumdar et al. 2007; Lewis et al. 2013). All lines were maintained on a $129 \mathrm{~S} 4$ coisogenic background, except for Bim, which was crossed into the Fgfr1/2-deficient backgrounds after only six generations of backcrossing to 129S4 and Irs2, was on a mixed background.

Generation of Fgfr2-FLAG3x expression vector and stable 3 T3 expression lines

An Fgfr2 isoform "c" cDNA isoform was PCR amplified from pri-

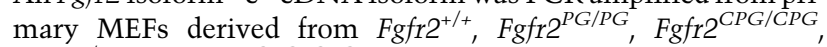
$F g f r 2^{F / F}$, and Fgfr2 ${ }^{F C P G F C P G}$ and subsequently digested with HindIII and XhoI. The fragments were cloned in the pcDNA expression vector and sequence verified. Linearized pcDNA-FGFR2 plasmids were transfected in $3 \mathrm{~T} 3$ cells cultured in DMEM 
supplemented with $10 \%$ calf serum with $50 \mathrm{U} / \mathrm{mL}$ each penicillin and streptomycin. Stable clones were selected in $500 \mu \mathrm{g} / \mathrm{mL}$ G418. Ten clones from each construct (FGFR2 ${ }^{\text {WT }}$-FLAG3x, FGFR2 ${ }^{\text {PG }}$-FLAG3x, FGFR2 ${ }^{\text {CPG }}$-FLAG3x, FGFR2 ${ }^{\mathrm{F}}$-FLAG3x, or FGFR $2^{\text {FCPG }}$-FLAG3x) were expanded and assessed for FLAG expression by Western blot. Clones expressing high FGFR2-FLAG levels were selected for further analysis.

\section{Coimmunoprecipitation and Western blotting}

Stable $3 \mathrm{~T} 3$ cells expressing FGFR2 ${ }^{\mathrm{WT}}, \mathrm{FGFR}^{\mathrm{PG}}$, FGFR2 ${ }^{\mathrm{CPG}}$,

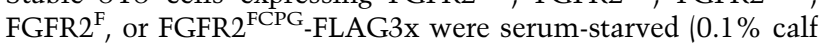
serum supplemented DMEM) overnight, stimulated for $15 \mathrm{~min}$ with 50 ng/mL FGF1 (PeproTech 450-33A) or FGF8b (PeproTech $100-25 \mathrm{~B}$ ) and $5 \mu \mathrm{g} / \mathrm{mL}$ heparin (Sigma H3149), and lysed in icecold NP-40 lysis buffer $(20 \mathrm{mM}$ Tris HCL at pH 8, $137 \mathrm{mM}$ $\mathrm{NaCl}, 10 \%$ glycerol, $1 \%$ Nonidet [NP-40], 2 mM EDTA, 25 $\mathrm{mM} \beta$ glycerol phosphate, $1 \mathrm{mM} \mathrm{Na}_{3} \mathrm{VO}_{4}, 10 \mathrm{mM} \mathrm{NaF}, 1 \times \mathrm{cOm}-$ plete, EDTA-free protease inhibitor cocktail [Sigma 11836153001]). Eight-hundred micrograms of cell lysates was subsequently used for immunoprecipitation with anti-FLAG M2 magnetic beads (Sigma M8823) using the manufacturer's protocol. We incubated lysates with anti-FLAG M2 magnetic beads overnight at $4^{\circ} \mathrm{C}$ followed by five washes with lysis buffer, and precipitated proteins were eluted in Laemmli buffer (10\% glycer$\mathrm{ol}, 2 \%$ SDS, $0.002 \%$ bromophenol blue, $0.062 \mathrm{M}$ Tris- $\mathrm{HCl}$ at $\mathrm{pH}$ 6.8) containing $10 \% \beta$-mercaptoethanol, heated for $5 \mathrm{~min}$ at $95^{\circ} \mathrm{C}$, separated by SDS-PAGE, and analyzed by Western blots.

Western blot analysis was performed according to standard protocols using horseradish peroxidase-conjugated secondary antibodies (1:10,000 dilution) developed by chemiluminescent HRP substrate. Primary antibodies were used at the following dilutions for Western blotting: FGFR2 (1:500 dilution; Abcam ab109372), CRKL (1:500 dilution; Santa Cruz Biotechnology sc319), FRS2 (1:500 dilution; Santa Cruz Biotechnology sc8318), FLAG2 M2 (1:500 dilution; Sigma F1804), phospho-p44/42 MAPK (1:1000 dilution; CST 9101), p44/42 MAPK (1:1000 dilution; CST 9102), GAPDH (1:1000 dilution; ProteinTech 60004), phospho-AKT (1:1000 dilution; CST 4060), AKT (1:1000 dilution; CST 9272), phospho-p38 (1:500 dilution; CST 4511), p38 (1:500 dilution; CST 9212), phospho-PLC $\gamma 1$ (Y783; 1:200 dilution; CST 2821), PLC $\gamma 1$ (1:1000 dilution; CST 2822), pJNK (1:500 dilution; CST 4671), phospho-STAT3 (Y705; 1:500 dilution; CST 9145) STAT3 $a$ (1:1000 dilution; CST 8768), phospho-FAK (1:1000 dilution; CST 3283), FAK (1:1000 dilution; CST 3285), Irs2 (1:500 dilution; CST 3089), $\beta$-catenin (1:1000 dilution; CST 8480), and Paxillin (1:1000 dilution; Abcam ab32084). For signaling pathways analyzed, the blots were quantified for three independent biological replicates using ImageLab6.0 analysis tool. Ratio of average of mean intensity value of pERK $1 / 2$, pAKT, pPLC $\gamma 1$, pJNK, pSTAT3a, pP38 to $\mathrm{GAPDH} \pm$ standard deviation was plotted for each pathway.

\section{Cell derivation and culture conditions}

Primary iFNPs were generated by dissecting the maxillary and nasal prominences of E11.5 $\mathrm{Fgfr}^{+/+}{ } \mathrm{Ink}^{-/-}, \mathrm{Fgfr}^{\mathrm{F} / \mathrm{F}} ; \mathrm{Ink}^{-/-}$, Fgfr2 ${ }^{C P G / C P G} ; I^{-1-} k^{-/}$, and E9.5 or E11.5 Fgfr2 ${ }^{F C P G / F C P G} ;$ Ink $^{-/-}$embryos in PBS. The tissue was disassociated with $0.125 \%$ TrypsinEDTA (Thermo Fisher 25200) and cultured in DMEM (Sigma D5796) supplemented with 20\% FBS (HyClone SH30396.03), $50 \mathrm{U} / \mathrm{mL}$ each penicillin and streptomycin (Gibco P0781) on fibronectin-coated (Sigma FC010) plates $\left(0.5 \mu \mathrm{g} / \mathrm{cm}^{2}\right)$. Cells were subsequently split 1:5 through for at least five passages before immortalized cell lines were obtained. Cells were allowed to grow until subconfluent. All experiments were performed between passage 15 and 25. We used PX459 V2.0 vector (Addgene plasmid 62988) to CRISPR out either Fgfr1 or Fgfr2 and create Fgfr1-null, Fgfr2-null, or Fgfr1;Fgfr2-double-null cells. gRNA sequences for Fgfr1 and Fgfr2 were selected using the CHOPCHOP gRNA design web tool and were cloned using the oligonucleotides (Supplemental Table S4), as previously described (Ran et al. 2013). Plasmids were transfected in respective iFNP cells cultured in DMEM supplemented with $10 \%$ calf serum (HyClone SH30072.03) with $50 \mathrm{U} / \mathrm{mL}$ each penicillin and streptomycin. Stable clones were selected in $5 \mu \mathrm{g} / \mathrm{mL}$ Puromycin (Sigma P8833). Clones were verified (homozygous deletion of exon 6 for Fgfr 1 and deletion exon 5 for $F g f r 2$, which also introduces a frameshift mutation) using PCR (Supplemental Table S4). Primary MEFs were derived from E12.5 wild-type mouse embryos. Embryos were eviscerated and after removing the head, remaining tissue was chopped into $1-\mathrm{mm}$ pieces and incubated in $1 \mathrm{~mL}$ of Trypsin-EDTA $(0.25 \%)$ for $30 \mathrm{~min}$ with intermittent shaking. Ten milliliters of DMEM/10\% calf serum was added and the mixture was allowed to pass through a cell strainer. Cells collected from each embryo were plated in $0.2 \%$ gelatin-coated $15-\mathrm{cm}$ plates.

\section{Cell-matrix interactions}

To study cell-matrix interactions, wild-type serum starved cells in suspension were treated with FGF1 (50 ng/mL FGF1, $5 \mu \mathrm{g}$ / $\mathrm{mL}$ heparin), with or without Infigratinib (BGJ398; Selleckchem S2183), an FGFR1/2/3 kinase inhibitor. Equal numbers of cells were plated on fibronectin-coated coverslips and cell spreading was quantified over a 90-min period during which cells attached to the matrix. The average number of cells per field was quantified for each treatment. Similar experiments were carried out with $\mathrm{Fgfr} 1^{\text {CRISPR-KO }} ; \mathrm{Fgfr}^{+/+}, \quad \mathrm{Fgfr} 1^{\text {CRISPR-KO }} ; \mathrm{Fgfr} 2^{\mathrm{KD} / K D}$ and

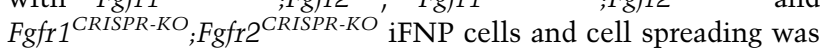
assessed and quantified upon treatment with either FGF1, PDGF-AA, or serum treatment. Paxillin ${ }^{+}$focal adhesion formation (upon 3-h treatment) in various conditions was further used to assess cell-matrix interactions.

\section{Skeletal preparations}

Embryos at E14.5, E16.5, or E18.5 embryos were skinned, eviscerated, fixed in $95 \%$ ethanol overnight, and stained $10.015 \%$ Alcian blue, $0.005 \%$ Alizarin red, $5 \%$ glacial acetic acid, in $70 \%$ ethanol) overnight at $37^{\circ} \mathrm{C}$. Skeletons were then cleared in $1 \% \mathrm{KOH}$ and transferred to decreasing concentrations of $\mathrm{KOH}$ in increasing concentrations of glycerol until clear.

\section{Acetocarmine and hematoxylin and eosin staining}

Freshly harvested tissue was fixed in $4 \%$ PFA at $4{ }^{\circ} \mathrm{C}$ overnight, followed by dehydration in $70 \%$ ethanol. For acetocarmine staining, tissues were incubated in $0.5 \%$ aceto-carmine (Sigma C1022; $0.5 \mathrm{~g}$ of carmine stain dissolved in $100 \mathrm{~mL}$ of boiling $45 \%$ acetic acid for $15 \mathrm{~min}$ ), followed by destaining in $70 \%$ ethanol for 1 min and $1 \%$ acid alcohol $(1 \% \mathrm{HCl}$ in $70 \%$ ethanol) for $2 \mathrm{~min}$ and $5 \%$ acid alcohol $(5 \% \mathrm{HCl}$ in $70 \%$ ethanol) for $1 \mathrm{~min}$. For hematoxylin and eosin staining, freshly harvested tissues were dissected in PBS, and fixed in 4\% PFA followed by dehydration through a graded ethanol series, and embedded in paraffin. $5-\mu \mathrm{m}$ sections were cut. After deparaffinization and rehydration, sections were stained with Harris-modified hematoxylin (Sigma HHS16), followed by a $10-\mathrm{sec}$ wash in acid-alcohol (1\% [v/v] $\mathrm{HCl}$ in $70 \% \mathrm{EtOH})$, followed by counterstaining with $1 \%$ eosinY 
(Sigma 17372-87). Tissues were washed and mounted with Permount.

\section{Scratch assays}

Cells were seeded onto glass coverslips coated with $5 \mu \mathrm{g} / \mathrm{mL}$ human plasma fibronectin purified protein. At $\sim 90 \%-100 \%$ confluency, cells were scratched with a P1000 pipet tip, washed with PBS and incubated in fresh medium containing either $0.1 \%$ FBS, $10 \%$ FBS, $50 \mathrm{ng} / \mathrm{mL}$ FGF1, and $5 \mu \mathrm{g} / \mathrm{mL}$ heparin or $10 \mathrm{ng} /$ mL PDGF-AA supplemented DMEM for $12 \mathrm{~h}$.

\section{Immunofluorescence and antibodies}

For immunostaining whole-mount embryos were fixed in $4 \%$ paraformaldehyde solution (PFA) in PBS overnight and washed with PBS five times, permeabilized with $0.5 \%$ Triton X-100 in PBS for $30 \mathrm{~min}$, and blocked in 5\% BSA for $2 \mathrm{~h}$ at room temperature. Primary anti-neurofilament antibody (DSHB clone $2 \mathrm{H} 3$ ) was used at a 1:20 dilution in 5\% BSA in PBST; embryos were incubated overnight at $4{ }^{\circ} \mathrm{C}$. The next day, embryos were washed four times in PBST and incubated with anti-mouse HRP-conjugated secondary antibodies at a 1:1000 dilution for $4 \mathrm{~h}$ at room temperature followed by washing in PBST four times and signal was developed using ImmPACTDAB kit (Vector Laboratories SK4105). For whole-mount immunofluorescence at E7.5, embryos were fixed overnight in 4:1 methanol:DMSO. Primary antibodies for Eomes (Abcam \#ab2335; 1:100 dilution) and Cdx2 (1:100 dilution; Biogenex MU392A) were used. For immunostaining cells, cells were fixed for $10 \mathrm{~min}$ in $4 \%$ PFA in PBS at room temperature. Cells/tissues were subsequently processed for immunofluorescence analysis as detailed above using anti-paxillin primary antibody (1:250 dilution; Abcam 23345) with Alexa647 conjugated phalloidin (1:40 dilution). For immunofluorescence on sections, antibodies for GFP (1:100 dilution), mCherry (1:100 dilution) and SMA (1:100 dilution) was used. Embryos were stained with DAPI following fixation as previously described (Sandell et al. 2012). Cells and tissues were photographed using a Leica SP5 confocal microscope, or a Hamamatsu C11440 camera fitted to a Zeiss Observer Z1 microscope. Epifluorescence was imaged using a Zeiss Axioplan fitted to a ProgRes CT3 camera.

\section{In situ hybridization}

Labeled antisense RNA probes were synthesized for Alx3, Msx1, Six3, Nkx2.1, Fgf8, Shh, Col2a1, Col10a1, and Meox1. Digoxigenin-labeled antisense probes were generated as described, and mRNA in situ hybridization on paraffin sections for chromogenic detection was performed using standard protocols.

\section{Micro-CT imaging}

Micro-CT imaging of the skulls were performed using a SkyScan 1172 scanner (Bruker). The mouse heads were dissected and fixed in $10 \%$ neutral buffered formalin and washed and stored in PBS at $4^{\circ} \mathrm{C}$. The skull bones were scanned with settings of $50 \mathrm{kV}, 500 \mu \mathrm{A}$, $10-\mu \mathrm{m}$ pixel resolution, $0.3^{\circ}$ rotation steps, and four frames average imaging with a $0.5-\mathrm{mm}$ Al filter at the Micro-CT Core, School of Dentistry, New York University, New York. The acquired Xray projections were reconstructed using the Imaris software (Oxford Instruments).

\section{Cell proliferation assay}

For EdU labeling in mice, pregnant females were injected intraperitoneally with $100 \mathrm{mg} / \mathrm{kg}$ body weight of EdU. EdU detection was carried out as per the manufacturer's instruction for Click-iT EdU cell proliferation kit (Thermo Fisher Scientific \#C10340).

\section{TUNEL assay}

Sections were deparaffinized and were rehydrated in PBS, followed by postfixation in 4\% PFA. In situ cell death detection kit (Roche 12156792910), TMR red user protocol was used to detect cell death. The number of TUNEL-positive foci were normalized to the number of DAPI-stained nuclei to quantify the extent of cell death for MNP and LNP across various genotypes. TUNEL and DAPI channels from LNP and MNP were manually cropped individually from acquired images and background fluorescence was reduced using brightness, contrast, and $\gamma$ settings equally for all images. Fgfr1 ${ }^{+/ c K O} ; \mathrm{Fgfr}^{+/ c K O}$ and $\mathrm{Fgfr}^{+/ c K O}$; Fgfr2 ${ }^{c K O / c K O}$ mutants did not show significant numbers of TUNEL-positive foci/pixel, in contrast to $\mathrm{Fgfr}^{\mathrm{cKO} / \mathrm{cKO} \text {; }}$ Fgfr2 ${ }^{\text {cKO/cKO }}$ mutants.

\section{$R T-q P C R$}

Cells were lysed, and mRNA was extracted according to Qiagen RNeasy kit (Qiagen 74106) standard protocol. cDNA was synthesized using a 2:1 ratio of random primers to Oligo(dT) with SuperScript IV RT (Thermo Fisher 18090050). qPCR was performed with PerfeCTa SYBR Green FastMix for iQ (VWR 101414-264) with Bio-Rad iQ5 multicolor real-time PCR detection system and analyzed with Bio-Rad iQ5 optical system software (version 2.0). Cycling conditions were as follows: step $1,3 \mathrm{~min}$ at $95^{\circ} \mathrm{C}$; step 2, $10 \mathrm{sec}$ at $95^{\circ} \mathrm{C}$; step $3,30 \mathrm{sec}$ at $60^{\circ} \mathrm{C}$; repeat steps 2 and 3 for 40 cycles. Proper amplification was confirmed using a melting curve and by running samples on a gel to ensure that the correct size band was obtained. Graphs were made using Microsoft Excel and Prism. Primer sequence for respective genes used for RT-qPCR analysis is listed below.

\section{$\beta$-Catenin quantification}

Cells were stained and imaged using a Leica SP5 confocal microscope under identical conditions. Stacks were then background subtracted using a 100px rolling ball function in ImageJ. The average pixel intensity along cell-cell junctions was measured in a single z-plane per junction using a 15-pixel line width in ImageJ for the EGFP and $\beta$-catenin channels.

\section{Quantification and statistical analysis}

Statistical analysis was performed using GraphPad Prism6.0 and Microsoft Excel. Values are presented as mean \pm standard deviation. The statistical significance was determined using a Student's $t$-test with Holm-Sidak method.

\section{Acknowledgments}

We thank Jia Li and Chantel Dixon for technical assistance; Kevin Kelley for stable tissue culture facilities; Elaine Fuchs for helpful insights into cell adhesion mechanisms; Jerry Chipuk for conversations about cell death; and our laboratory colleagues, Stu Aaronson, Rob Krauss, and Sergei Sokol for critical comments on the manuscript. We thank the New York University School of Dentistry Micro-CT Core and the Mt. Sinai Flow Cytometry and 
Microscopy facilities for assistance and advice. C.J.D. was supported by F32 DE026678 from National Institutes of Health (NIH)/National Institute of Dental and Craniofacial Research (NIDCR). This work was supported in part by the Tisch Cancer Institute at Mount Sinai (P30 CA196521 Cancer Center Support Grant, for access to Mt. Sinai cores) and by grant RO1 DE022778 from NIH/NIDCR to P.S.

Author contributions: P.S., A.T.R., and P.M. conceived the project and planned the experimental approach. A.T.R. generated the bulk of the craniofacial morphogenesis, biochemical, and cell adhesion studies. P.M. performed the initial characterization of signaling mutants. J.R.B. obtained the initial craniofacial phenotypes. C.C. generated all of the signaling mutant targeting constructs. C.J.D. performed embryo and cell imaging. P.S. generated the KD targeting constructs and all of the mouse strains, and directed the project. Data were analyzed by A.T.R., P.M., C.J.D., and P.S. The manuscript was written by A.T.R. and P.S. with edits from all authors.

\section{References}

Bellot F, Crumley G, Kaplow JM, Schlessinger J, Jaye M, Dionne CA. 1991. Ligand-induced transphosphorylation between different FGF receptors. EMBO J 10: 2849-2854. doi:10.1002/j .1460-2075.1991.tb07834.x

Borges E, Jan Y, Ruoslahti E. 2000. Platelet-derived growth factor receptor $\beta$ and vascular endothelial growth factor receptor 2 bind to the $\beta_{3}$ integrin through its extracellular domain. $J$ Biol Chem 275: 39867-39873. doi:10.1074/jbc.M007040200

Bouillet P, Metcalf D, Huang DC, Tarlinton DM, Kay TW, Kontgen F, Adams JM, Strasser A. 1999. Proapoptotic Bcl-2 relative Bim required for certain apoptotic responses, leukocyte homeostasis, and to preclude autoimmunity. Science 286: 1735-1738. doi:10.1126/science.286.5445.1735

Brewer JR, Molotkov A, Mazot P, Hoch RV, Soriano P. 2015. Fgfr1 regulates development through the combinatorial use of signaling proteins. Genes Dev 29: 1863-1874. doi:10.1101/gad .264994 .115

Brewer JR, Mazot P, Soriano P. 2016. Genetic insights into the mechanisms of Fgf signaling. Genes Dev 30: 751-771. doi:10 $.1101 / \mathrm{gad} .277137 .115$

Chipuk JE, Green DR. 2008. How do BCL-2 proteins induce mitochondrial outer membrane permeabilization? Trends Cell Biol 18: 157-164. doi:10.1016/j.tcb.2008.01.007

Ciruna B, Rossant J. 2001. FGF signaling regulates mesoderm cell fate specification and morphogenetic movement at the primitive streak. Dev Cell 1: 37-49. doi:10.1016/S1534-5807(01) 00017-X

Clybouw C, Merino D, Nebl T, Masson F, Robati M, O'Reilly L, Hübner A, Davis RJ, Strasser A, Bouillet P. 2012. Alternative

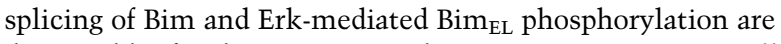
dispensable for hematopoietic homeostasis in vivo. Cell Death Differ 19: 1060-1068. doi:10.1038/cdd.2011.198

Czabotar PE, Lessene G, Strasser A, Adams JM. 2014. Control of apoptosis by the BCL-2 protein family: implications for physiology and therapy. Nat Rev Mol Cell Biol 15: 49-63. doi:10 $.1038 / \mathrm{nrm} 3722$

Danielian PS, Muccino D, Rowitch DH, Michael SK, McMahon AP. 1998. Modification of gene activity in mouse embryos in utero by a tamoxifen-inducible form of Cre recombinase. Curr Biol 8: 1323-1326. doi:10.1016/S0960-9822(07)00562-3

De Moerlooze L, Spencer-Dene B, Revest JM, Hajihosseini M, Rosewell I, Dickson C. 2000. An important role for the IIIb isoform of fibroblast growth factor receptor 2 (FGFR2) in mesen- chymal-epithelial signalling during mouse organogenesis. Development 127: 483-492.

Deng CX, Wynshaw-Boris A, Shen MM, Daugherty C, Ornitz DM, Leder P. 1994. Murine FGFR-1 is required for early postimplantation growth and axial organization. Genes Dev 8: 3045-3057. doi:10.1101/gad.8.24.3045

Endo Y, Ishiwata-Endo H, Yamada KM. 2012. Extracellular matrix protein anosmin promotes neural crest formation and regulates FGF, BMP, and WNT activities. Dev Cell 23: 305-316. doi:10.1016/j.devcel.2012.07.006

Eswarakumar VP, Ozcan F, Lew ED, Bae JH, Tome F, Booth CJ, Adams DJ, Lax I, Schlessinger J. 2006. Attenuation of signaling pathways stimulated by pathologically activated FGF-receptor 2 mutants prevents craniosynostosis. Proc Natl Acad Sci 103: 18603-18608. doi:10.1073/pnas.0609157103

Fantauzzo KA, Soriano P. 2017. Generation of an immortalized mouse embryonic palatal mesenchyme cell line. PLoS One 12: e0179078. doi:10.1371/journal.pone.0179078

Francavilla C, Cattaneo P, Berezin V, Bock E, Ami D, de Marco A, Christofori G, Cavallaro U. 2009. The binding of NCAM to FGFR1 induces a specific cellular response mediated by receptor trafficking. I Cell Biol 187: 1101-1116. doi:10.1083/jcb .200903030

Francavilla C, Rigbolt KT, Emdal KB, Carraro G, Vernet E, Bekker-Jensen DB, Streicher W, Wikström M, Sundström M, Bellusci S, et al. 2013. Functional proteomics defines the molecular switch underlying FGF receptor trafficking and cellular outputs. Mol Cell 51: 707-722. doi:10.1016/j.molcel .2013 .08 .002

Frisch SM, Francis H. 1994. Disruption of epithelial cell-matrix interactions induces apoptosis. I Cell Biol 124: 619-626. doi:10.1083/jcb.124.4.619

Garg A, Bansal M, Gotoh N, Feng GS, Zhong J, Wang F, Kariminejad A, Brooks S, Zhang X. 2017. Alx4 relays sequential FGF signaling to induce lacrimal gland morphogenesis. PLoS Genet 13: e1007047. doi:10.1371/journal.pgen.1007047

Geiger B, Yamada KM. 2011. Molecular architecture and function of matrix adhesions. Cold Spring Harb Perspect Biol 3: a005033. doi:10.1101/cshperspect.a005033

Grabow S, Kueh AJ, Ke F, Vanyai HK, Sheikh BN, Dengler MA, Chiang W, Eccles S, Smyth IM, Jones LK, et al. 2018. Subtle changes in the levels of BCL-2 proteins cause severe craniofacial abnormalities. Cell Rep 24: 3285-3295.e4. doi:10.1016/j .celrep.2018.08.048

Griffin JN, Compagnucci C, Hu D, Fish J, Klein O, Marcucio R, Depew MJ. 2013. Fgf8 dosage determines midfacial integration and polarity within the nasal and optic capsules. Dev Biol 374: 185-197. doi:10.1016/j.ydbio.2012.11.014

Hanks SK, Quinn AM, Hunter T. 1988. The protein kinase family: conserved features and deduced phylogeny of the catalytic domains. Science 241: 42-52. doi:10.1126/science.3291115

Hoch RV, Soriano P. 2006. Context-specific requirements for Fgfr1 signaling through Frs2 and Frs3 during mouse development. Development 133: 663-673. doi:10.1242/dev.02242

Hosokawa R, Deng X, Takamori K, Xu X, Urata M, Bringas P Jr., Chai Y. 2009. Epithelial-specific requirement of FGFR2 signaling during tooth and palate development. I Exp Zool B Mol Dev Evol 312B: 343-350. doi:10.1002/jez.b.21274

Kang M, Garg V, Hadjantonakis AK. 2017. Lineage establishment and progression within the inner cell mass of the mouse blastocyst requires FGFR1 and FGFR2. Dev Cell 41: 496-510.e5. doi:10.1016/j.devcel.2017.05.003

Karuppaiah K, Yu K, Lim J, Chen J, Smith C, Long F, Ornitz DM. 2016. FGF signaling in the osteoprogenitor lineage non-autonomously regulates postnatal chondrocyte proliferation and 
skeletal growth. Development 143: 1811-1822. doi:10.1242/ dev.131722

Klinghoffer RA, Hamilton TG, Hoch R, Soriano P. 2002. An allelic series at the PDGFaR locus indicates unequal contributions of distinct signaling pathways during development. Dev Cell 2: 103-113. doi:10.1016/S1534-5807(01)00103-4

Kon E, Calvo-Jiménez E, Cossard A, Na Y, Cooper JA, Jossin Y. 2019. N-cadherin-regulated FGFR ubiquitination and degradation control mammalian neocortical projection neuron migration. Elife 8: e47673. doi:10.7554/eLife.47673

Kurowski A, Molotkov A, Soriano P. 2019. FGFR1 regulates trophectoderm development and facilitates blastocyst implantation. Dev Biol 446: 94-101. doi:10.1016/j.ydbio.2018.12.008

Lanner F, Rossant J. 2010. The role of FGF/Erk signaling in pluripotent cells. Development 137: 3351-3360. doi:10.1242/dev .050146

Lei K, Davis RJ. 2003. JNK phosphorylation of Bim-related members of the Bcl2 family induces Bax-dependent apoptosis. Proc Natl Acad Sci 100: 2432-2437. doi:10.1073/pnas.0438011100

Lemmon MA, Schlessinger J. 2010. Cell signaling by receptor tyrosine kinases. Cell 141: 1117-1134. doi:10.1016/j.cell.2010 .06 .011

Lewis AE, Vasudevan HN, O'Neill AK, Soriano P, Bush JO. 2013. The widely used Wnt1-Cre transgene causes developmental phenotypes by ectopic activation of Wnt signaling. Dev Biol 379: 229-234. doi:10.1016/j.ydbio.2013.04.026

Li P, Elowitz MB. 2019. Communication codes in developmental signaling pathways. Development 146: dev170977. doi:10 $.1242 /$ dev. 170977

Mailleux AA, Overholtzer M, Schmelzle T, Bouillet P, Strasser A, Brugge JS. 2007. BIM regulates apoptosis during mammary ductal morphogenesis, and its absence reveals alternative cell death mechanisms. Dev Cell 12: 221-234. doi:10.1016/j .devcel.2006.12.003

McQuade KJ, Beauvais DM, Burbach BJ, Rapraeger AC. 2006. Syndecan- 1 regulates $\alpha_{v} \beta_{3}$ and $\alpha_{v} \beta_{5}$ integrin activity in B82L fibroblasts. J Cell Sci 119: 2445-2456. doi:10.1242/jcs.02970

Meyer M, Muller AK, Yang J, Moik D, Ponzio G, Ornitz DM, Grose R, Werner S. 2012. FGF receptors 1 and 2 are key regulators of keratinocyte migration in vitro and in wounded skin. J Cell Sci 125: 5690-5701. doi:10.1242/jcs.108167

Molotkov A, Mazot P, Brewer JR, Cinalli RM, Soriano P. 2017. Distinct requirements for Fgfr1 and Fgfr2 in primitive endoderm development and exit from pluripotency. Dev Cell 41: 511-526.e4. doi:10.1016/j.devcel.2017.05.004

Moser M, Legate KR, Zent R, Fassler R. 2009. The tail of integrins, talin, and kindlins. Science 324: 895-899. doi:10.1126/sci ence. 1163865

Muzumdar MD, Tasic B, Miyamichi K, Li L, Luo L. 2007. A global double-fluorescent Cre reporter mouse. Genesis 45: 593-605. doi: $10.1002 / \mathrm{dvg} .20335$

Nieto MA, Huang RY, Jackson RA, Thiery JP. 2016. Emt: 2016. Cell 166: 21-45. doi:10.1016/j.cell.2016.06.028

Ornitz DM, Itoh N. 2015. The fibroblast growth factor signaling pathway. Wiley Interdiscip Rev Dev Biol 4: 215-266. doi:10 $.1002 /$ wdev.176

Park EJ, Watanabe Y, Smyth G, Miyagawa-Tomita S, Meyers E, Klingensmith J, Camenisch T, Buckingham M, Moon AM. 2008. An FGF autocrine loop initiated in second heart field mesoderm regulates morphogenesis at the arterial pole of the heart. Development 135: 3599-3610. doi:10.1242/dev .025437

Partanen J, Schwartz L, Rossant J. 1998. Opposite phenotypes of hypomorphic and Y766 phosphorylation site mutations reveal a function for Fgfrl in anteroposterior patterning of mouse embryos. Genes Dev 12: 2332-2344. doi:10.1101/gad.12.15 .2332

Ran FA, Hsu PD, Wright J, Agarwala V, Scott DA, Zhang F. 2013. Genome engineering using the CRISPR-Cas9 system. Nat Protoc 8: 2281-2308. doi:10.1038/nprot.2013.143

Rapraeger AC, Krufka A, Olwin BB. 1991. Requirement of heparan sulfate for bFGF-mediated fibroblast growth and myoblast differentiation. Science 252: 1705-1708. doi:10.1126/ science.1646484

Rasouli SJ, El-Brolosy M, Tsedeke AT, Bensimon-Brito A, Ghanbari P, Maischein HM, Kuenne C, Stainier DY. 2018. The flow responsive transcription factor Klf2 is required for myocardial wall integrity by modulating Fgf signaling. Elife 7: e38889. doi:10.7554/eLife.38889

Raymond CS, Soriano P. 2007. High-efficiency FLP and ФC31 site-specific recombination in mammalian cells. PLoS One 2: e162. doi:10.1371/journal.pone.0000162

Raymond CS, Soriano P. 2010. ROSA26Flpo deleter mice promote efficient inversion of conditional gene traps in vivo. Genesis 48: 603-606. doi:10.1002/dvg.20659

Rice R, Spencer-Dene B, Connor EC, Gritli-Linde A, McMahon AP, Dickson C, Thesleff I, Rice DP. 2004. Disruption of Fgf10/Fgfr2b-coordinated epithelial-mesenchymal interactions causes cleft palate. I Clin Invest 113: 1692-1700. doi:10.1172/JCI20384

Sandell LL, Kurosaka H, Trainor PA. 2012. Whole mount nuclear fluorescent imaging: convenient documentation of embryo morphology. Genesis 50: 844-850. doi:10.1002/dvg.22344

Scarpa E, Szabó A, Bibonne A, Theveneau E, Parsons M, Mayor R. 2015. Cadherin switch during EMT in neural crest cells leads to contact inhibition of locomotion via repolarization of forces. Dev Cell 34: 421-434. doi:10.1016/j.devcel.2015.06.012

Serrano M, Lee H, Chin L, Cordon-Cardo C, Beach D, DePinho RA. 1996. Role of the INK4a locus in tumor suppression and cell mortality. Cell 85: 27-37. doi:10.1016/S0092-8674(00) 81079-X

Shigetani Y, Nobusada Y, Kuratani S. 2000. Ectodermally derived FGF8 defines the maxillomandibular region in the early chick embryo: epithelial-mesenchymal interactions in the specification of the craniofacial ectomesenchyme. Dev Biol 228: 73-85. doi:10.1006/dbio.2000.9932

Simon MA, Bowtell DD, Dodson GS, Laverty TR, Rubin GM. 1991. Ras1 and a putative guanine nucleotide exchange factor perform crucial steps in signaling by the sevenless protein tyrosine kinase. Cell 67: 701-716. doi:10.1016/0092-8674(91) 90065-7

Sims-Lucas S, Cullen-McEwen L, Eswarakumar VP, Hains D, Kish K, Becknell B, Zhang J, Bertram JF, Wang F, Bates CM. 2009. Deletion of Frs2a from the ureteric epithelium causes renal hypoplasia. Am J Physiol Renal Physiol 297: F1208F1219. doi:10.1152/ajprenal.00262.2009

Steinberg Z, Myers C, Heim VM, Lathrop CA, Rebustini IT, Stewart JS, Larsen M, Hoffman MP. 2005. FGFR2b signaling regulates ex vivo submandibular gland epithelial cell proliferation and branching morphogenesis. Development 132: 1223-1234. doi:10.1242/dev.01690

Sun J, Stathopoulos A. 2018. FGF controls epithelial-mesenchymal transitions during gastrulation by regulating cell division and apicobasal polarity. Development 145: dev161927. doi:10 $.1242 /$ dev.161927

Sun X, Meyers EN, Lewandoski M, Martin GR. 1999. Targeted disruption of Fgf8 causes failure of cell migration in the gastrulating mouse embryo. Genes Dev 13: 1834-1846. doi:10.1101/ gad.13.14.1834 
Ray et al.

Tallquist MD, Soriano P. 2000. Epiblast-restricted Cre expression in MORE mice: a tool to distinguish embryonic vs. extra-embryonic gene function. Genesis 26: 113-115. doi:10.1002/ (SICI)1526-968X(200002)26:2<113::AID-GENE3>3.0.CO;2-2

Tallquist MD, French WJ, Soriano P. 2003. Additive effects of PDGF receptor $\beta$ signaling pathways in vascular smooth muscle cell development. PLoS Biol 1: E52. doi:10.1371/journal .pbio.0000052

Thamodaran V, Bruce AW. 2016. P38 (Mapk14/11) occupies a regulatory node governing entry into primitive endoderm differentiation during preimplantation mouse embryo development. Open Biol 6: 160190. doi:10.1098/rsob.160190

Trumpp A, Depew MJ, Rubenstein JL, Bishop JM, Martin GR. 1999. Cre-mediated gene inactivation demonstrates that FGF8 is required for cell survival and patterning of the first branchial arch. Genes Dev 13: 3136-3148. doi:10.1101/gad .13.23.3136

Ueno H, Gunn M, Dell K, Tseng A Jr., Williams L. 1992. A truncated form of fibroblast growth factor receptor 1 inhibits signal transduction by multiple types of fibroblast growth factor receptor. J Biol Chem 267: 1470-1476.

Vasudevan HN, Mazot P, He F, Soriano P. 2015. Receptor tyrosine kinases modulate distinct transcriptional programs by differential usage of intracellular pathways. Elife 4: e07186. doi:10 $.7554 /$ eLife.07186

Wang C, Chang JY, Yang C, Huang Y, Liu J, You P, McKeehan WL, Wang F, Li X. 2013. Type 1 fibroblast growth factor receptor in cranial neural crest cell-derived mesenchyme is required for palatogenesis. I Biol Chem 288: 22174-22183. doi:10.1074/ jbc.M113.463620
Williams EJ, Furness J, Walsh FS, Doherty P. 1994. Activation of the FGF receptor underlies neurite outgrowth stimulated by L1, N-CAM, and N-cadherin. Neuron 13: 583-594. doi:10 $.1016 / 0896-6273(94) 90027-2$

Withers DJ, Gutierrez JS, Towery H, Burks DJ, Ren JM, Previs S, Zhang Y, Bernal D, Pons S, Shulman GI, et al. 1998. Disruption of IRS-2 causes type 2 diabetes in mice. Nature 391: 900-904. doi:10.1038/36116

Xu X, Weinstein M, Li C, Naski M, Cohen RI, Ornitz DM, Leder P, Deng C. 1998. Fibroblast growth factor receptor 2 (FGFR2)mediated reciprocal regulation loop between FGF8 and FGF10 is essential for limb induction. Development 125: 753-765.

Yamaguchi TP, Harpal K, Henkemeyer M, Rossant J. 1994. fgfr-1 is required for embryonic growth and mesodermal patterning during mouse gastrulation. Genes Dev 8: 3032-3044. doi:10 $.1101 /$ gad.8.24.3032

Yayon A, Klagsbrun M, Esko JD, Leder P, Ornitz DM. 1991. Cell surface, heparin-like molecules are required for binding of basic fibroblast growth factor to its high affinity receptor. Cell 64: 841-848. doi:10.1016/0092-8674(91)90512-W

Youle RJ, Strasser A. 2008. The BCL-2 protein family: opposing activities that mediate cell death. Nat Rev Mol Cell Biol 9: 47-59. doi:10.1038/nrm2308

Yu K, Xu J, Liu Z, Sosic D, Shao J, Olson EN, Towler DA, Ornitz DM. 2003. Conditional inactivation of FGF receptor 2 reveals an essential role for FGF signaling in the regulation of osteoblast function and bone growth. Development 130: 30633074. doi:10.1242/dev.00491

Zinkle A, Mohammadi M. 2018. A threshold model for receptor tyrosine kinase signaling specificity and cell fate determination. F1000Res 7: 872. doi:10.12688/f1000research.14143.1 


\section{CORRIGENDUM}

Genes \& Development 34: 1735-1752 (2020)

\section{Corrigendum: FGF signaling regulates development by processes beyond canonical pathways}

Ayan T. Ray, Pierre Mazot, J. Richard Brewer, Catarina Catela, Colin J. Dinsmore, and Philippe Soriano

The above-mentioned article contained an error in Figure 6A. Two panels shown in the scratch assay of serum-treated Fgfr1 $1^{+/ c K O} ; \mathrm{Fgfr} 2^{+/ c K O}$ and Fgfr $1^{c K O / c K O} ; \mathrm{Fgfr} 2^{c K O / c K O}$ cells were the same, as the wrong file was used for the Fgfr1 ${ }^{+/ c K O}$; Fgfr2 ${ }^{+/ c K O}$ panel. Figure 6 has now been corrected in the article online. The conclusions of the manuscript are not affected as all cells spread equivalently under these conditions. The authors apologize for this error.

doi: $10.1101 / \operatorname{gad} .348503 .121$ 


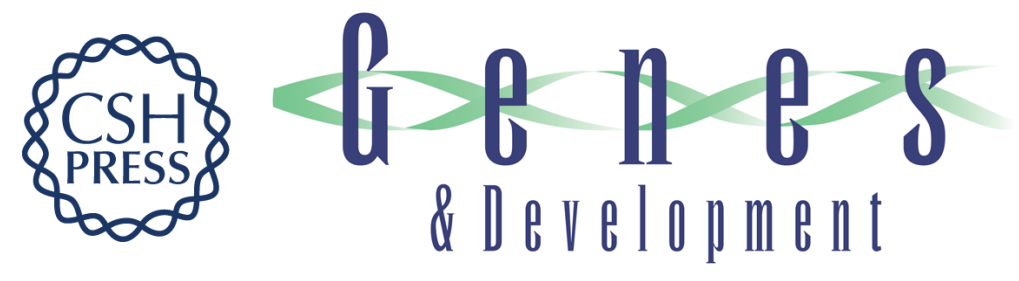

\section{FGF signaling regulates development by processes beyond canonical pathways}

Ayan T. Ray, Pierre Mazot, J. Richard Brewer, et al.

Genes Dev. 2020, 34: originally published online November 12, 2020

Access the most recent version at doi:10.1101/gad.342956.120

\section{Supplemental http://genesdev.cshlp.org/content/suppl/2020/11/11/gad.342956.120.DC1 Material}

Related Content

Corrigendum: FGF signaling regulates development by processes beyond canonical pathways

Ayan T. Ray, Pierre Mazot, J. Richard Brewer, et al. Genes Dev. May , 2021 35: 783

References This article cites 75 articles, 31 of which can be accessed free at: http://genesdev.cshlp.org/content/34/23-24/1735.full.html\#ref-list-1

Articles cited in: http://genesdev.cshlp.org/content/34/23-24/1735.full.html\#related-urls

Creative This article is distributed exclusively by Cold Spring Harbor Laboratory Press for the first Commons six months after the full-issue publication date (see

License http://genesdev.cshlp.org/site/misc/terms.xhtml). After six months, it is available under a Creative Commons License (Attribution-NonCommercial 4.0 International), as described at http://creativecommons.org/licenses/by-nc/4.0/.

Email Alerting Receive free email alerts when new articles cite this article - sign up in the box at the top Service right corner of the article or click here.

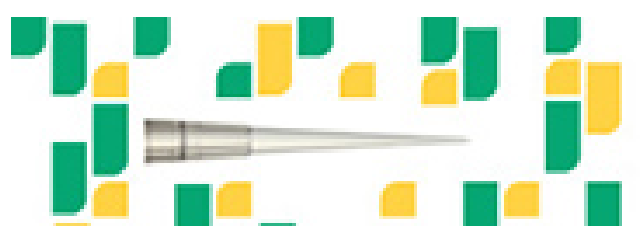

Focused on your science. 